\title{
Terrorism versus insurgency: a conceptual analysis
}

\author{
Mustafa Coșar Ünal ${ }^{1}$
}

Published online: 21 January 2016

(C) Springer Science+Business Media Dordrecht 2016

\begin{abstract}
This study analyzes the distinction between terrorism and insurgency by drawing upon the case of the PKK conflict in Turkey. It provides a conceptual discussion through multi-dimensional analyses from the actor-oriented, the actionoriented, the purpose-oriented, and the ontology-oriented perspectives. In so doing, in addition to the organizational characteristics, it critically identifies the PKK's varying strategies of terrorist and insurgent violence, and their temporality and reasoning as the conflict unfolded to make conceptual inferences. This study found, first, that while the PKK as an actor indicates an insurgent character, the PKK's use of violence reflects intense terrorism action particularly after its military defeat. Second, the use of terrorism by the PKK reflects an inextricable overlap in temporality and a direct link with guerilla methods. Despite the PKK's terrorist and insurgent violence resulted from different factors and reasoning at the intermediate level; they are designed to converge at the overall aim of the PKK's political campaign. Third, the PKK violence reflects varying purposes of terrorism, e.g., intimidation, attrition, survival and group solidarity. Fourth, after reaching the tipping point that resulted in its military defeat in 1994, the PKK resorted to more indirect and asymmetrical violence in an increasing tendency to deflect state power and, thus, to coerce Turkey into a political compromise, i.e., a negotiated settlement.
\end{abstract}

\section{Introduction}

Distinguishing terrorism from other forms of political violence, particularly from insurgency, has raised questions about how to conceptualize terrorism. The different character and types of terrorism and other forms of political violence, along with the underlying reasons for an intrastate conflict, are the centerpieces of the discussion. Analyzing varying types of political violence together rather than separately to identify

Mustafa Coșar Ünal

mcosarunal@yahoo.com; cosar.unal@bilkent.edu.tr

1 Department of Political Science and Public Administration, Adjunct at Bilkent University, Ankara, Turkey 
how they relate to one another has been considered important lately in the literature. It is particularly crucial to analyze why and when these types of violence coexist, complement, substitute one another, and overlap during different phases of conflicts $[19,58]$.

The Kurdistan Workers' Party (PKK), a violent uprising of dissident Kurds in Turkey with a deep-rooted historical background and 36 years of struggle against the Turkish State, offers a significant case to analyze in terms of the diverse and varying characteristics of violence that occurred over the span of the conflict. In this regard, by drawing upon the literature, this study provides a multi-perspective analysis from various angles related to actor-based, action-based, ontology-based, and purposebased approaches, with particular focus on the characteristics of violence in order to analyze different types of terrorism and insurgent methods.

The PKK conflict is one of the longest-lasting and still active intrastate conflicts with significant regional impact in the recent history of Turkey and the neighboring Middle East [71]. The conflict has yielded a high death toll resulting in 39,476 fatalities (including PKK militants) of which 5478 were civilians, and 6764 were security personnel. ${ }^{1}$ In the meantime, 26,774 PKK militants were killed, another 922 were injured, 6727 were captured, and 4781 surrendered between 1984 and 2013. ${ }^{2}$ In its prolonged struggle, the PKK evolved in different phases, each reflecting varying characteristics of violence based on internal (tit for tat against the Turkish State) and external political dynamics. In this regard, it is important to identify when and why violent movements resort to different forms of terrorism; and how the changing character of violence relates to certain strategies, which were embraced based on internal and external dynamics of the conflict. Finally, as emerged in the third wave of modern terrorism or in the socialist insurgent wave of the post-cold war era, the PKK conflict constitutes a rich source which can be used to make conceptual inferences on the typology and character of political violence based on perspectives and concepts discussed in the literature.

Turkey, by presenting the issue solely as a terrorism problem, implemented intense securitization policies for many years. Only after the early 2000s did Turkey adopt certain social and political reforms to accommodate certain Kurdish grievances. With the diplomatic efforts of the Turkish State, the PKK has been listed as a terrorist organization by the United States and Australia since 2001, by Canada in 2002, and by the European Union in 2002. However, certain other states, particularly in Europe, consider PKK activities in their respective countries to be purely political.

Apart from this governmental stance based mainly on politics, academic studies have depicted the PKK as a terrorist organization [e.g., 2, 6, 62], an insurgency movement, Kurdish guerillas and rebels [e.g., 8, 35, 36, 44, 77]. Such heterogeneity in defining the PKK issue resulted in use of different concepts each of which would imply a distinctive approach of countermeasures. This raises some significant questions. First, what is the PKK; and, what is the nature of the different phases of PKK violence in the context of the overall conflict? How do different types of terrorism and guerilla insurgent attacks relate to each other and to the periodic objectives and the

\footnotetext{
${ }^{1}$ Fatalities refer to number of killed only while casualties (in Table 1) refer to number of both killed and injured.

${ }^{2}$ Fatality and casualty figures are extracted from the Turkish National Police, Intelligence Department Database.
} 
overall goal of the PKK? How and when the indirect and asymmetrical use of violence is vital for the inferior actor, i.e., the PKK? The existing literature, however, lacks a comprehensive analysis of the varying characteristics of violence that have occurred in the 30 years of the PKK conflict in terms of the typology of political violence and the relationship of the characteristics to one another. Against this background, this article analyzes terrorism versus insurgency, different types of terrorism, and the myriad of factors leading to different types of violence, using the PKK as a case study.

Toward these ends, this study provides different angles to analyze the conflict. These include the action-based perspectives, i.e., the character and form of violence, the short, mid and long term purpose and more importantly, the target status of violence; and an actor-based analysis that discusses the overall characteristics of the PKK's organizational structure and management, level of active or tacit popular support, and the nature of political goal. In addition to these, this article will briefly discuss the ontology of the PKK conflict, with its emergence, social construction and historical roots. However, since the historical-ontological factors of this case are highly subjective and valueladen, the focus in this article is on action and actor-oriented criteria.

This study puts particular emphasis on the directness of challenge, in which ways, purpose and results of PKK violence are analyzed in terms of their link to the PKK's declared grievances, causes and goals, ${ }^{3}$ in addition to the nature of their target status (combatants and non-combatants), character and selectivity of the violence. How the use of violence relates to the periodic strategies and overarching goals of the PKK suggest important underpinnings in the use of violence for different strategic purposes, particularly terrorist versus insurgent attacks. This approach helps not only identify directness of challenge but also different strategies of terrorism in a broader conflict. In so doing, however, this article does not attempt to ascribe any legal status to the PKK, nor does it make any inferences about the PKK conflict based on international law; rather, this article offers an academic perspective. ${ }^{4}$

This study is structured in three parts. First, there is a conceptual discussion of the definitions of terrorism and insurgency in the broad context of an intrastate war from action and actor-oriented perspectives and ontological factors. Second, after briefly discussing the ontological perspective of social construction and causes of the PKK's rise in Turkey, the study reviews the organizational characteristics of the PKK and applies actor-oriented approaches to the PKK case. In that it analyzes the PKK's organizational structure, its management body, level of popular support devoted to the PKK, and the PKK's declared goals. Third, the study analyzes action-based criteria of the nature (directness), form (target status, location, incident type), and purpose of violence. In that, it analyzes how different characteristics of terrorist and insurgent violence relate to the PKK's periodic objectives as well as its overarching goal. The analysis of the form and nature of PKK violence uses incident-level quantitative data from four different institutional and governmental databases; and identifies the purpose of PKK violence through qualitative data from original pro-PKK sources such as

\footnotetext{
3 PKK's ontological factors refers to the grievance and cause as claimed and declared by the PKK.

${ }^{4}$ More specifically, where the PKK would stand, for instance, in the three echelon spectrum of armed conflicts not of an international character, namely rebellion, insurgency, and belligerency, or how the ascription of the PKK's status would be according to other international law considerations such as the Geneva Convention of 1949 and additional protocol II of 1977 are considered to be a separate discussion of customary and conventional international law and thus it is beyond the scope of this analysis.
} 
resolutions and bulletins from PKK Congresses and Conferences. ${ }^{5}$ The final section offers concluding remarks.

\section{Theoretical discussion: terrorism, insurgency, and guerilla warfare}

Different terminology characterizes political violence. Conceptualization efforts for different forms of political violence yield no agreement as to how to operationalize each of these terms according to a solid typology (prospective) and taxonomy (retrospective) based on clear and definitive criteria. This is because there exists no common understanding and perception of ethics, history and politics $[52,53]$. Thus, the context of the discussion is value laden and consists of subjective conditions rather than objective historical factors [13]. Within this context, terrorism, no doubt, is the most contentious term based on its perceived illegitimacy, negative connotations, and intensity of use.

There are studies focusing on the conceptual definition of terrorism [13, 22, 25, 60, 61]; its role in the context of civil war [19, 31, 33, 58]; and the relationship of terrorism to other forms of political violence as a tactic and method [27, 38]. Distinguishing terrorism from other forms of political violence, including insurgency, has been at the center of such discussions, particularly in the context of the characteristics of terrorism that reflect multiple perspectives. Most approaches are action-based with focus upon identifying target status and violence [22, 27, 33, 38, 58]. There are also multiple actorbased studies discussing characteristics of perpetrators [see, 59]. Certain studies use the target audience as their basis for conceptualizing terrorism [see, 37]. Moreover, there are legal approaches striving to define terrorism [e.g., 24]. Typological approaches classify and distinguish different types of terrorism [e.g., 38, 63]. Finally, certain studies focus on the ontological factors to identify the characteristics of violent uprisings, focusing on the perceived legitimacy of the cause in the sense of greed versus grievance [for more discussion on this see, 7, 23].

The bulk of existing studies, however, uses criteria that are said to simultaneously exist for terrorism, e.g., a sub-state organization, use or threat of use of violence against non-combatant civilians, and apolitical motive/goal [13, 25, 60, 61]. Among these perspectives, the action-oriented approach questioning the nature, form and purpose of violence has been most prevalent. This is because violence is, in a sense, the tool/ resource rather than the final product for a violent group pursuing a political end [33]. It is considered an important commodity for insurgents to mobilize popular support and to make political gains [79]. In other words, violence is the term of trade for insurgent groups seeking a negotiated settlement in a conflict, as in the PKK case after the 2000s. Thus, analyzing the character and form of violence and understanding its purpose are crucial matters both for understanding the conflict and for developing effective countermeasures.

In fact, the need to study different forms of political violence together rather than separately has gained prominence lately. Findley and Young [19p. 286] argued that "[S]cholars often privilege the study of one form of contention over another,"

\footnotetext{
5 The PKK congresses were periodic (every four years) while the conferences were sporadic or on ad hoc basis until 2000, when the PKK held a transformational Congress and reformed itself under different names.
} 
indicating the tendency to implicitly and explicitly study different forms of political violence. Isolating these different forms of violence might result in overlooking the question of why and when these types of violence coexist, complement and substitute one another. They identify a particular relationship between terrorism and civil war (onset, during, and after) and suggest that there might be connections between various types of political violence during different phases of conflicts [19]. However, while accepting terrorism as a strategy, Sambanis [58] emphasized that terrorism is (and should be conceptualized as) a distinct form of political violence with separate causes, and also argued that terrorism in most cases cannot evolve into civil war except through the use of terrorism in the initial stages of an insurgency. Merari [46], on the other hand, argued that circumstances rule out what insurgents embrace as a strategy and mode of struggle rather than what they choose and, particularly lately, insurgents exploit terrorism whenever possible because it is one of the easiest modes of struggle.

Conflict conditions are not hardly changing structures and thus it is easy to observe the evolution of a conflict (i.e., escalation, transition) among different forms of political violence [57]. From this perspective, intrastate conflicts that reflect protracted asymmetric warfare characteristics are considered to simultaneously have different characteristics and forms of political violence employed to achieve different ends [4]. Thus, the concept of asymmetric conflict encompasses many forms of political violence including civil war, terrorism and insurgency [5]. Most of the discussion applies also to the civil war context due to that the fact that, as James Fearon [17] argued, most civil wars, since 1945, have started as insurgencies. So, identifying the dynamics of different forms of political violence in the broad context of a conflict requires understanding their relationship, distinction, and overlap.

Among varying forms of political violence, as Kydd and Walter [38] argued, terrorism is a costly form of signaling, using intimidation, provocation, attrition, outbidding and spoiling. However, this analytical classification is based on a very broad definition of terrorism that only reflects the basic tenets of action (targeting civilians), actor (by non-state actors), and purpose/motivation (political goal), which clearly avoids the critical distinction between civil war, insurgency and terrorism. Notwithstanding, from an integrated point of view, it helps to categorize how and why insurgent groups resort to terrorism before, during and after the conflict, in and out of the context of a civil war.

This distinction matters because of the connotations behind these terms. Terrorism is considered to be a pejorative term. Guerilla warfare and insurgency, by contrast, carry a greater degree of legitimacy due to their association with liberation, freedom fighters, etc., and are mostly used as a counter argument for terrorism in political disputes between conflicting parties. The bottom line for definitional disputes about these terms is the degree of legitimacy or lack thereof and the end goal of the ontology of a violent uprising, which is highly subjective and ideological due to the self-proclamation of righteousness.

In this light, definitions, particularly for terrorism, are contestable by nature and might not be conclusive because of the subjectivity of the political aim and intentions for resorting to violence that determine the legitimacy of the cause [7, 23]. Often these are actor-centric rather than action-centric, therefore carrying a subjective judgment. Yet, efforts to conceptualize different forms of political violence lack clear classifying criteria, and any attempt to do so results in applying ad hoc coding criteria due to 
conceptual ambiguity [58]. However, despite this subjectivity and divergence in definitional attempts, there are certain technical characteristics that are dispersedly presented in the literature to differentiate terrorism and insurgency and their relation to one another. This study regroups and briefly discusses these perspectives in the following paragraphs: method versus movement; the directness of challenge/fight ${ }^{6}$; nature of political goal; level of popular support; organizational/administrative structure and nature of management body; and form (target status) and character of violence. It should be noted that transnational terrorism has different dynamics than intrastate conflict/domestic terrorism [58]. This analysis mostly applies to domestic terrorism because the PKK is homegrown and mostly home directed, with victims and audience stemming from the host country of Turkey.

Method versus movement Terrorism is considered to be a method of pursuing a political goal [19], while insurgency is a political movement aimed at realizing a specific political goal [65, para. 2], which is generally to overthrow a regime. Whether terrorism is a separate phenomenon or part of a broader strategy of insurgency in the context of a civil war is a matter of debate. Sambanis [58], for instance, underlined differences in factors when resorting to terrorism as opposed to civil war and argued that there can be multiple terrorisms as strategies (exclusively outside of the civil war context), each with a different purpose and reason. Findley and Young [19], on the other hand, suggested that analytical distinctions between terrorism and civil war might be misleading and that terrorism is conducted as a complementary/supplementary action that occurs as a byproduct of political claim making (mostly during war and then in post war periods). In her typological approach, i.e., international vs. domestic, motivational (nationalist, religious, etc.), functional (classic, conflict-related, and super/ mega terrorism), Stepanova $[63,10]$ classified "conflict-related terrorism," according to the functional typology, in which she indicated the use of terror as a tactic in a broader armed conflict, i.e., in mostly insurgencies and civil war contexts.

It is commonly cited that terrorism is a tool that is used by insurgent groups in their broader strategy in civil wars $[38,58]$ and, as of recently, in contemporary armed conflicts [63]. In certain cases, insurgencies do not explicitly employ terrorism and deliberately renounce it due to legitimacy concerns, mostly in anti-colonial insurgencies. In others, the insurgency reflects a concern for broad, publicly acknowledged legitimacy for a declared goal (e.g., Al-Qaeda). Connable and Libicki [12] claimed that terrorism is used in broad insurgent campaigns, emphasizing that recent insurgencies publicly renounce terrorism but make use of it. For the recent case of the Islamic State in Iraq and Syria (ISIS/ISIL or DAESH) has proven adaptive and has sought territorial gains; however, it simultaneously uses terrorist and insurgent tactics and offers public apologies for its terrorist attacks. ${ }^{7}$

In the generic sense, however, intrastate insurgencies mostly employ guerilla warfare as a method. Thus, in certain cases, guerilla warfare is synonymous with insurgency $[20,25]$ and these two terms are combined into "guerilla insurgency" [30]. This is mostly because the term "guerrilla" is associated with small wars and refers to the way

\footnotetext{
${ }^{6}$ Directness of challenge in this study particularly questions the relevancy between the nature, form, and purpose of the violence employed and the ontological factors of the violent uprising.

${ }^{7}$ Indeed, al-Qaida broadly (and ISIS specifically) cannot easily be subsumed under any one typology.
} 
in which a non-state armed resistance is employed against the ruling government. A number of groups that embraced the Marxist Theory of the People's War (e.g., Mao Tse Tung, General Giap) used guerilla warfare, ${ }^{8}$ which aimed to create a revolutionary movement by mobilizing the peasantry from rural to urban areas [55]. Given the fact that insurgency is a violent struggle between the ruling state with a regular army and an opposing non-state actor with no regular army [41], the common use of guerilla warfare by insurgents is not surprising given the great asymmetry between the earlier and the state (Terrorism Research n.d., para. 3).

Insurgencies, having a politico-military nature, use social, political, and economic means, in addition to military efforts in their broader political campaign [49]. The principal strategy for insurgencies is the use of violence within the context of direct, armed struggle in asymmetric modes of warfare for political claim making [34]. Given their politico-military characteristics, insurgents directly challenge the "political authority" with the leading instrument of a political campaign and the supplementary instrument of a military campaign in a civil war context [21].

The characteristics of violence in the context of civil war, however, have undergone significant changes. Insurgencies have used terrorism as a method in recent decades, when compared with insurgent movements of the mid-20th century anti-colonial years, based on cost-benefit rationales such as the mitigated chance of military victory against conventional armies [34]. Since waging a solid and constant guerilla fight against state forces is costly, insurgencies increasingly resort terrorist tactics. For provocation purposes, for instance, the high impact of terrorist attacks using advanced technology generates easier and faster publicity when compared with the cost of sustaining an everyday guerilla fight in a protracted war against a state army. Therefore, terrorist methods have been used strategically for revolutionary purposes in addition to and within the insurrectionary of violent opposition. This is where Crenshaw's concept of revolutionary terrorism [14] comes into play in an intrastate conflict between a nonstate actor and a state. Likewise, Stepanova $[639,13]$ uses the term "militant-terrorist group," indicating the difference between terrorist organizations and organizations that use terror and other violent, mostly guerilla, methods simultaneously for varying but not conflicting purposes. As explained later, the PKK resorted to terrorism in different periods of its struggle and for different purposes, as identified by Kydd and Walter's [38] five strategies of terrorism: provocation, attrition, intimidation, outbidding, and spoiling [cf. 27].

From their inception, insurgencies evolve with significant changes in their methods to resolve certain organizational dilemmas such as action vs. secrecy, growth vs. control, and success vs. longevity. Insurgencies take internal and external contextual factors under consideration in adjusting and adapting their overall strategy and for meeting their changing objectives. This is what makes conflicts unique in terms of their context within which the violent group emerges and evolves [20]. Thus, different forms of political violence, terrorism in particular, emerge for different purposes and reasons reflecting varying strategies.

\footnotetext{
${ }^{8}$ The first two stages in Mao's theory includes guerilla workforce while the final stage, if the first two are successful, three is a regular army in which the guerrillas become strong and form a regular army to face their counterparts on 'conventional' terms.
} 
Directness of challenge/fight Insurgencies directly oppose the state's authority [30] and challenge the regime [41] through politico-military actions intended to weaken the control of a constituted government through an organized protracted war [50]. Terrorists, however, are mostly marginalized underground groups employing indirect violence [58] to create public fear, intimidation, and anxiety in order to evoke political reaction [22, 61] and political response [14], rather than directly attacking political authority or its representatives, e.g., security forces. This is because terrorism rarely brings about a political change on its own [34]. There exist organizations, such as Al Qaeda, that resort only to terrorist attacks to evoke emotional responses from societies and actions from targeted political authorities for global and non-negotiable political impact [63]. In the national context, for instance, the Real Irish Republican Army (RIRA, a split group from Provisional Irish Republican Army, [P]IRA) chose armed struggle as an underground terror organization employing violence.

In terrorism, there exists a clear discrepancy between the magnitude of violence [58, 59] and the scale of the designated goal (extreme asymmetry). In this respect, terrorism is an indirect way to reach a political end, as opposed to insurgency, which directly attacks the defined enemy with asymmetric war tactics. As opposed to the typical nature of an insurgency fighting against a ruling regime in a specific geographical area, terror groups seek political change through sensational attacks on symbolic or indirect (non-combatant) civilian targets [58]. Insurgencies, however, strive for a change in the respective regime through the direct challenge of state forces with systematic and organized violence as part of a political campaign.

Nature of political goal There is no clear-cut difference between the goals of terrorist groups and insurgencies, but certain characteristics might reflect distinctions. In terrorism, for instance, there is an extreme asymmetry between the strength and magnitude of the violence and the scale of the overall goal. Insurgencies, however, reflect less divergence from that perspective. Insurgencies, by definition, are designed to realize their designated goals with direct action (particularly insurgencies of the anti-colonial years), while terrorist goals require action from the targeted state, political authority or population. As Fearon [17] argued, the generic logic of terrorism works not because it creates fear but because it invokes governments and individuals to respond to terrorist demands. Insurgencies, however, tend to have more of a direct link between their action (both military and political) and their goal.

The level of violence that insurgents create leads them, as Sambanis [58] mentioned, to have broader goals in terms of magnitude and scale. Insurgents also tend to have periodic objectives in their evolution as the conflict unfolds and as the power balance changes between the state and the insurgents. Such conditions tend to result in insurgent goals that are more specific and attainable with direct action, as opposed to the goals of terrorist groups, which tend to stay more general and vague in nature. Kydd and Walter [38] framed terrorist goals into five different categories. The first two categories, regime and territorial change are general, while policy change, social control, and status quo maintenance tend to be more specific. This is because, as previously mentioned, Kydd and Walter [38] rely on a very broad definition of terrorism (similar to states' legal approaches). On the other hand, "Superterrorism" or "Mega/Macro-terrorism," a term by used Stepanova [63, 10], that defines transnational global terror organizations such as Al-Qaeda and related 
groups, reflect a goal that is "existential, non-negotiable, global, and in this sense unlimited" nature.

Terrorist groups might have also specific interim demands (e.g., release of their captured members) from the state authority in addition to their overarching goal. But this is different from goals of insurgents, which, as adaptive entities, might modify their goals periodically for pragmatic reasons, when their overarching goal is far from being realized for that period.

Level of popular support Terrorist groups do not necessarily need support from a large population; they exploit the high impact of sensational attacks on symbolic targets to trigger an aggressive reaction $[14,45]$ without legitimacy concerns. Terrorism is thus considered to be the most asymmetrical of all types of political violence [63]. Insurgencies need large populations to support their cause [58], as well as their politicomilitary campaign $[30,41]$. Sustaining a protracted war requires tremendous active and tacit support in terms of new recruits, logistics, and finances, etc.

Organizational/administrative structure and nature of management body As opposed to the underground clandestine nature of cell structured terrorist groups in terms of leadership, organizational structure and formation [45, 59], insurgents are not clandestine and are broader in their functions, with political and military wings acting simultaneously and in concert [30]. There exists a central decision making mechanism, and a recognizable representative management body that can reveal intent and openness for political talks and that can engage in negotiations with state authorities. Insurgents are capable of forming traditional military-like groups since they have a systematic centralized organization and flexibilities in certain rural areas that are out of reach from state's control [58]. Another difference between terrorists and insurgents is territorial control [59]. If not in full control of a territory, insurgents may achieve temporary dominance in certain areas, keeping visible wherever the government's security apparatus is weak. Certain parts of the populace will know about their existence in certain areas. As Fearon [17] specified, for the last 50 years of civil wars, insurgents tend to have control in mostly rural areas at night, while days belong to security forces, particularly in urban strongholds.

Form and nature of violence The selection of the target is the most basic perspective to distinguish terrorism from insurgency based on an action-oriented approach. If noncombatant civilians are deliberately threatened or targeted as part of an indirect challenge to convey the perpetrators' message, then it is considered terrorism. Focusing on target status is largely due to subjectivity and value-laden ontology of violent opposition (i.e., the perspective of jus ad bellum). Ganor [22] argued, from a humanitarian perspective, a solid distinction can be made between guerilla warfare and terrorism by referring to international law and principals such as the Hague and Geneva Conventions, which define terrorism as the peacetime, equivalent to war crimes. If military and security personnel are the only targets of political violence, then it can be considered as an insurgency. Otherwise, if violence is imposed on non-combatant civilians, then it is considered to be terrorism (government staff are considered to be non-combatants unless they are in decision making positions in the state's counterterrorism policy). Stepanova [63] also indicated that making civilians the direct target of 
violence is one of the determinant criteria of terrorism. Barber [7] argues, however, that applying such a straightforward definition based on target status is problematic. Using the criteria of targeting civilian non-combatants to refer to terrorism does not consider the legitimacy of the overall aim. Nor it is concerned with the actors who are employing violence for political purposes, such as a sub-state group, non-ruling entity, party, or underground group. Tilly [66] agreed that terrorism is a strategy that can be used by any actor in various contexts. Sambanis [58], nonetheless, argued that while non-combatant civilians are disproportionately targeted more when terrorism is used, it cannot be the determinant criteria because modern civil wars yield more civilian casualties [58]. Yet, definitions of combatant and non-combatant are not clear and are not easy to define [25, 34]. In most cases, there exist direct and indirect combatants and non-combatants that may complicate the distinction.

\section{The PKK}

This section, after discussing and applying the aforementioned criteria to the PKK case, focuses on the characteristics of PKK violence. In that, it employs multiple analyses that include and incorporate action-based, actor-based, purpose-based and ontologybased approaches along with the analysis of the directness of the challenge i.e., linking the nature of the violence to the PKK's declared cause, grievance and the overarching goal. Such an approach discusses the nature of the violence from jus in bello perspective, that is, illegitimacy versus legitimacy in how the fight is carried out. ${ }^{9}$ By relying on these perspectives, this section discusses PKK violence in the context of terrorism and insurgency, and questions its linkages and relations to one another. It portrays the structures and changing character of PKK violence as the conflict unfolds by thoroughly analyzing the PKK violence and its organizational characteristics.

\section{Organizational characteristics—actor based approach}

After providing a brief discussion of the PKK's ontology, this section analyzes the group's organizational characteristics using concepts discussed earlier. This section first provides a brief discussion of the social construction and emergence of the PKK to provide an insight into the historical background of the conflict. Second, it analyzes the strategy, nature of political goal, level of popular support, organizational structure, and the existence of a recognizable management body.

Emergence and social construction —ontology based approach Kurdish dissent is a deep-rooted issue and dates back to the Ottoman times. In the modern history of the Turkish Republic, there have been approximately 25 Kurdish uprisings, of which the Kurdistan Workers' Party (PKK) constitutes the latest and the bloodiest one. The PKK's emergence not only coincides with the nation-state phenomenon of the Cold

\footnotetext{
${ }^{9}$ As known, the jus in bello concept basically questions the justness (legitimacy) of how the war is conducted irrespective of the concept of jus ad bellum, which refers to why (the legitimacy of the cause) the war is started, which is very subjective (the Theory of Just War).
} 
War and post-Cold War era, but also with the "new left wave" that emerged worldwide and is characterized as the third wave of modern terrorism [54]. All these developments incited political expectation and opposition among Turkey's Kurds [8, 75]. A group that split from a socialist civilian activist organization emerged under the leadership of Abdullah Ocalan at the University of Ankara to establish the PKK in 1973 [69]. Inspired by anti-colonial examples such as the Cuban Revolution, the socialist segment of Kurds rallied around the notion of ethnic self-awareness. Once PKK-oriented activities moved to the southeastern part of Turkey, the PKK was officially founded on November 27, 1978 in the province of Diyarbakir-Lice. The group embraced the Maoist Strategy of People's War that aims to mobilize the revolution from rural to urban areas.

From the perspective of what causes civil wars, a vigorous debate in the literature, there are two major approaches: supply and demand. These are based on quantitative models in the rationalist approach of the economic logic of crime. ${ }^{10}$ While the supply side favored the opportunities for organizing insurgencies in a civil war [e.g., 10, 11, 18], the demand side found variables that are related to grievances of perceived social and political injustice, and economic inequality, known as the Theory of Relative Deprivation [26]. Taydas et al. [64], however, argued that factors contributing to a civil war might be grievance-based at one stage and opportunity-based at another.

Overall, one of the main approaches posits that three important points characterize the cause of civil wars: international characteristics of the post-Cold War era, social (religious and ethnic) fragmentation and deep-rooted ethnic and cultural differences, and failing governments [28, 29, 48]. However, Fearon and Laitin [18] suggested that the supply side approach is more about the insurgency theory, which points to the existence of weak government, rough terrain, foreign support, and access to weapons via ungoverned space, safe havens, and porosity of borders. In fact, both approaches help explain the emergence of the PKK conflict. The PKK's initial ideology of socialism, Turkey's socially diverse ethnic and religious structure, and the nationstate themed policies of respective governments in the 1970s can be explained using the demand approach. The harsh mountainous terrain of southeastern Anatolia, the unresponsive state policies toward legitimate Kurdish grievances, porosity of long borders with Iran, Iraq and Syria, the safe haven of Northern Iraq and the PKK's access to weapons over this area, and derived foreign support fit the supply approach.

Additionally, from the supply side, education, income (measured using various indicators), and job opportunities $[18,58]$ are strongly related to the PKK conflict. The Kurdish-inhabited area of northeastern Anatolia in Turkey has devastating socioeconomic conditions that provided fertile ground for the Kurdish uprising in Turkey. These included a low level of education, high unemployment, scarce job opportunities, and very low-income levels [73]. Problems with consolidated democracy, deficiencies of civil rights for Kurds, and other perceived social and political injustices and discrimination against the Kurdish minority are amongst other grievance-based factors $[8,35]$. The tribal structure (Agha system) is another prominent social formation in the Kurdish inhabited region $[74,76]$ that has had an impact on the PKK's social construction.

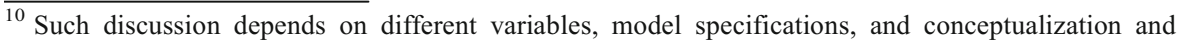
operationalization of variables but they are all beyond the scope of this study.
} 
The legitimacy of the uprising is the most subjective and value-laden part of the discussion. Thus, it is no surprise that there is no agreement on the social construction of the Kurdish uprising in Turkey. Some [cf. 39] argue that Kurdishness was just a politically constructed issue by national and international actors; whereas others [cf. 8, $16,35,50]$ point to the denial of certain individual rights and identity as the main source of grievances. The political approach underlines the difficulty of defining Kurds as a distinct nation in Turkey (this was the position of the Turkish state in its rhetoric about the Kurdish issue until the early 2000s); the grievance approach emphasizes the Turkish Republic's "nation state" denial policies, especially from the one-party era of 1923-1950 [cf. 1, 9, 16, 36]. ${ }^{11}$ However, the grievance approach has gained recent prominence, with the government's position transformed from counterterrorism to counterinsurgency, conflict management, and then conflict resolution.

Strategy Ocalan envisioned the PKK engaging in a guerilla fight in which all the Kurdish people were involved politically and militarily in a struggle for independence. The PKK, as inspired by the Cuban Revolution, embraced the Maoist Theory of People's War as suggested by the Chinese Insurgent Leader Mao Zedong. In that, a socialist revolution was to emanate from rural areas where the government authority was weaker to the urban areas of southeastern Turkey. However, as discussed later, the PKK resorted to terrorism at different times for different purposes.

The PKK's application of Maoist Theory involved only a guerilla fight, and there was no political effort until the early 1990s. Despite the PKK's attempt, as part of the third stage of Maoist Theory, to control territory by claiming small areas of land, the PKK did not go beyond the initial steps of the second stage (direct targeting of and attrition against the government authority in the region) due to Turkey's harsh military response, particularly in 1991-1994, and had to shift to different strategies discussed later.

Nature of political goal The PKK's its initial goal was the founding of a socialist Kurdish State comprised of territories from Iran, Syria, Iraq, and southeastern Turkey. However, the PKK, in its evolution, modified its original goal for strategic and pragmatic reasons [cf. 70]. After its acknowledgment of military defeat (in conventional sense) on the battlefield in 1994, and the capture of its founding leader Ocalan in 1999, the PKK's goal was limited to recognition of the Kurdish identity in the Constitution and the provision of certain political, cultural, and linguistic rights. Ocalan's capture had a significant impact on the PKK and its strategy, given the PKKs centralized and top-down organizational structure. After Ocalan's capture in 1999 and declaration of a long lasting ceasefire, the PKK shifted to intense political and diplomatic efforts, particularly in the international arena to force Turkey into a political compromise. To this end, the PKK abolished and reestablished itself twice (in 2002 as KADEK and in 2003 as KONGRA-GEL) with different rhetoric and strategies to distinguish itself from the bloody legacy of the previous PKK. However, the new PKK's self-legitimization effort failed and KONGRA-GEL was recognized as a continuation of the PKK terrorist organization by various countries and international organizations [cf. [69].

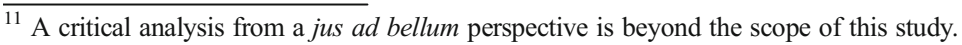


After the mid-2000s, the PKK shifted to a more politico-military campaign with creation of the Union of Kurdistan Communities (KCK) in 2007 to conduct social and political activities in concert with its military efforts [72]. In this context, the PKK replicated its initial goal in another form, named by Ocalan as the "Democratic Autonomy", demanding above all a federation, a regime change in Turkey, and finally an establishment of a form of self determination known as "Confederation" for Kurds in the southeastern region. Since then, the PKK stated that its goal would be the establishment of a decentralized administrative structure in which the disaffected Kurds of Turkey would have the right to local self-government according to the European Charter of Regional and Local Self-Government, that is, a form of self-determination. With the KCK, the PKK adopted a bottom-up approach of establishing a de facto autonomy (out-administration of governmental authority) and employed strategic violence as well as non-violent measures to force Turkey to negotiate a compromise. This is in contrast to the top-down approach of its early days that sought unilateral victory through guerilla warfare (namely, out-fighting Turkish Security Forces).

In addition, the PKK had certain demands, some of which included recognition of Kurdish identity in the Constitution, release of Ocalan (legalizing his return to political activity with house arrest) and the use of the Kurdish mother tongue in public education. As a result, the PKK reflects a typical insurgent character, with specific and attainable (not far from being realized) objectives for each evolutionary phase that are in alignment with its overarching political goal.

Level of popular support Kurds are not a homogenous ethnic group in terms of language, culture, religion, etc. This is true for the Kurds in Turkey. However, the Kurds in Turkey are viewed as two main groups: traditionalists who are integrated into all political, social, and economic aspects of governmental decision-making and power sharing, and benefit from the political and civil rights of the constitutional government; and socialists who claim to have been colonized by Turkey [16]. In the late 1960s and early 1970s, the divergence of these two groups became more obvious [3]. Today, such divergence continues with some marginal changes. The socialist segment, coming from a revolutionary approach, has always taken a stance for Kurdish independence. However, traditionalist Kurds consider themselves Sunni Muslims with religious motives integrated into mainstream society. While the socialist segment supports the PKK and its political wing parties, members of the traditionalist segment are suspicious of an unknown Kurdish entity [39] and support conservative parties, e.g., the ruling party named Justice and Development Party (AKP), and not pro-PKK parties. It should be noted however that Laciner and Bal's [39] argument was refuted in the latest national election results in 2015 as discussed below; most Kurds, including conservatives, supported the pro-PKK Peoples' Democratic Party (HDP), not the AKP, due to reasons, which are beyond the scope of this study.

In Turkey, the number of Kurds is a contentious issue given that is not even clear how to define Kurds. The questions that arise include "Who identifies as a Kurd?" or "Who can speak Kurdish?" and similar. It is commonly accepted that there is a population of approximately 14 to 20 million within the Turkish territory. Of this figure, approximately 5-7 million people support the PKK, according to the count of votes cast by the pro-PKK political parties in the latest national and local elections. Despite the fact that not all Kurds in Turkey support or sympathize with the PKK, 
almost one third of all Kurds in Turkey constitute considerable popular support for the PKK.

In the history of the PKK conflict, 10 pro-PKK Kurdish political parties have been established since 1989, when the first pro-PKK Kurdish political Party, the People's Labor Party, HEP was created. Throughout the process, five successive pro-PKK political parties were shut down by the Constitutional (Supreme) Court on the grounds that these political parties acted against the indivisible unity of the Turkish Republic. Another three parties abolished themselves and reformed into successor parties because of the potential for a government shutdown on the same grounds. While the latest Kurdish political party, the Peace and Democracy Party (Barıș ve Demokrasi Partisi, BDP) is still active, Kurds formed another political party named Peoples' Democratic Party (HDP) on October 12, 2012. HDP claims to appeal to the whole country and to embrace other ethnic segments of society rather than being a pure political wing party of the PKK and its sympathizers.

Due to the $10 \%$ threshold, the PKK had participated in the 2011 national elections with independent candidates by forming a pre-election coalition titled "Labor, Freedom, and Democracy Bloc". This bloc also included marginal extreme leftist political groups and political parties, e.g., The Party of Labor (EMEP) and the Socialist Party of the Oppressed (ESP), although they accounted for a very small portion of votes. The BDP, along with this bloc, cast 2,826,031 votes and gained 36 seats in the Turkish Grand National Assembly in the 2011 national election. In the local elections of 2014, the BDP increased its vote share up to $6.1 \%$ in total, together with the People's Democratic Party (HDP) (with BDP at $4.2 \%$ and HDP at $1.9 \%$ ), which had been established to gain support of not only Kurds but also socialists in the western provinces, similar to the Labor and Democracy Bloc of the past. BDP and HDP maintained support in three metropolitan municipalities of Diyarbakir, Van, and Mardin Provinces ${ }^{12}$ as well as many other provinces and counties in different percentages. ${ }^{13}$ However, the results from the latest national elections of 2015 resulted in a shocking success for the HDP. The HDP received $13.12 \%$ of the vote $(6,058,150)$ and not only surpassed the threshold but also gained 80 seats in the Parliament, which is equal to the seats that the deep-rooted Nationalist Movement Party (MHP) won with $16.29 \%$ of the vote. $^{14}$

Conclusively, the pro-PKK political parties have seen a steady pattern of popular support since the inception of the first Kurdish political party (HEP). They have received $4.1 \%$ (1991), $4.2 \%$ (1995), $4.8 \%$ (1999), $6.2 \%$ (2002), $5.2 \%$ (2007), $6.58 \%(2011)$, and 13.1 (2015) of the vote in national elections. So the HDP clearly passed the $10 \%$ threshold to make it to the Turkish Grand National Assembly (TBMM) and gained 80 seats in the latest national elections. The pattern of the local

\footnotetext{
${ }^{12}$ Mardin Province winner Ahmet Turk participated in the elections as an independent candidate. This is because he was banned from joining any political party and was expelled from the Turkish Grand National Assembly by the Constitutional Court decision of December 2009 on the account of being in connection with the PKK. He was elected as mayor of Mardin Province with the support of BDP.

${ }^{13}$ Data are extracted from High Board of Elections in Turkey, the official department for elections.

14 The HDP captured also certain level of strategic votes in the latest national elections in addition to supporting and sincerely voting Kurds.
} 
election results is similar: $3.4 \%$ (1999), $4.8 \%$ (2004), $5.7 \%$ (2009), and $6.1 \%(2014)$. ${ }^{15}$ Despite certain bans and closures, the pro-PKK Kurdish parties have maintained a considerable level of political activity in Turkey's municipal and national political system, and they have made use of certain legal opportunities. In addition, these parties have enabled PKK sympathizers to establish an institutional basis for collective and public gatherings, which could not have happened with the illegal apparatus of the PKK. Moreover, the PKK campaign was explicitly represented in the political spectrum, with marginalized PKK activists transformed into mainstream activists conducting public pro-Kurdish discourses [77]. So, in the history of the conflict, there has been an increasing trend in popular support for the PKK.

Organizational structure and recognizable management body Particularly after the early 1990s, the PKK evolved into a large and comprehensive organization with cross boundary ties. The PKK not only has subdivisions but also sub-organizations, each designed to serve a distinct purpose. However, the PKK was initially comprised of three main administrative bodies in which, until his capture, Ocalan was the sole leader and decision maker, with a "politburo" (a.k.a. the central committee), ERNK (The Liberation Front of Kurdistan, Eniya Rizgariya Netewa Kurdistan), and ARGK (Kurdish People's Liberation Army, Artese Rizgariya Gele Kurdistan) under his command. The ERNK, created in 1985, served as the political apparatus of the PKK and conducted political activities in and outside of Turkey, along with financing and lobbying for the acceptance of the PKK as a legitimate political representation of Turkey's Kurds. ARGK was the army of the PKK.

To maintain more popular support, the PKK created many sub-organizations targeting different segments of society, based on religion, sect, gender, age, clan, etc. Some of these included the Islamic Movement of Kurdistan (KIH) in 1994; Kurdistan Alaouite/Alawite (a specific Shi'a strand) Union (KAF/FEK) in 1993; and the Association of Compatriot Women (YKD). In recent years, the PKK changed its administrative structure and, starting in 2007, it has been managed under an umbrella organization known as the Union of Kurdistan Communities, KCK (discussed later).

The PKK is also systematically organizing in neighboring (e.g., Iraq, Iran, Syria) and European countries (e.g., Germany, Holland, Italy) through its front organizations. In so doing, the PKK receives logistical and financial support for its campaign. As a large organization networked in different countries, the PKK has engaged in legal fundraising activities through commercial businesses and support campaigns. However, the bulk of its revenue comes from illegal, organized criminal extortion activities. In its heyday in the early 1990s, for instance, the PKK received \$86 million (U.S.) annually. In recent years, this figure has reached to over $\$ 500$ million (U.S.) a year [56]. From this aspect, the PKK reflects a typical (politico-military) insurgency with its widespread sub-organizations and functions.

The PKK has always had a recognizable administration/leadership body. The current management body has a heavy military focus in Quandil Mountain in Northern Iraq. Other political leadership cadres are in Europe. The PKK has had a Stalinist

\footnotetext{
15 There exist certain important issues in reading the election results; such as, the demographic shift from east to west, feudal structure (bloc voting), fecundity rate difference between Kurds and Turks, etc. These are beyond the scope of this analysis.
} 
administrative organizational structure, in which a vertical hierarchy prevails, particularly in its military branch. This does not imply that the PKK leadership has a responsible command to enforce a disciplinary system; rather it underlines the PKK's organizational functions and leadership control.

As a matter of fact, Turkey has covertly attempted negotiations with this management body of the PKK. The most prominent was the Oslo peace process. This was a series of meetings between the parties of the PKK (including PKK's leadership cadre in Europe and Qandil, which was in touch with Ocalan through his attorney) and state intelligence officials [72]. The Oslo process started loosely in 2007, and accelerated in 2009 (a.k.a the Habur attempt). ${ }^{16}$ However, due to intense police operations that resulted in arrests of KCK members (non-violent Kurdish politicians, activists, academicians, etc.) and other reasons, the resolution process came to a halt in mid-2011. This resulted in Ocalan's declaration of a new era called "Strategic Lunge" in March 2010 and the PKK's declaration of de facto autonomy through an all-out people's war in July 2011. In late 2012, the Turkish government took a new stance from a conflict resolution perspective called the "Peace/Resolution Process," which was publicly announced at the Nevruz 2013 Celebration in Diyarbakir province in a message from Ocalan and lasted until July 2015, when it has fractured due to internal and external factors that are considered beyond the scope of this study [72].

\section{Analysis of PKK violence—action based approach}

This section focuses on the action-based perspective and discusses the character/nature, form and purpose of PKK violence in the context of directness of challenge to illustrate how the PKK conducted its fight. Due to their interrelated natures, target status, directness of the challenge, and the methods used by the PKK are simultaneously analyzed through the scope of PKK's chronological evolution. As the core piece of the study, the linkage of PKK violence - whether direct or indirect - related to its ontological factors, is incorporated into the analysis to explain the PKK's characteristics and changing character in the context of terrorism, revolutionary terrorism, guerilla warfare, and insurgency. In that, the use of violence that is indirectly linked to the ontological factors of a violent movement is considered to have low legitimacy, as in the notion of terrorism in which violence is directed against indirect or symbolic targets.

Rather than solely looking at the overall counts of violent incidents and related target status, this section focuses also on the form, purpose, and location of violence to make inferences on the character and characteristics of violence. In so doing, it first presents figures and trends of civilian and combatant casualties; then it analyzes these characteristics in the PKK's evolution for the entire span of the conflict (1984-2013), and relates them to the PKK's original causes, grievances and goals, as well as to the contextual political and strategic dynamics of the Turkish State and the PKK. This approach identifies the PKK's resort to terrorism in terms of different strategies, i.e.,

\footnotetext{
${ }^{16}$ In 2009, the Turkish Government adopted a series of democratization policies toward the Kurdish issue, which is known as "Democratic Opening," or "Kurdish Opening," or "National Brotherhood Project". This process has been disrupted when the first peace group (a group of PKK members) entered the country from the Habur Border Gate (Iraq border) because of demonstrations and were perceived as the PKK's victory parade by the mainstream society. The government renounced and suspended the project for that period.
} 
attrition, provocation, intimidation, outbidding, and spoiling, as categorized by Kydd and Walter [38].

Target status On August 15, 1984, the PKK commenced its warfare campaign against the Turkish Republic with two attacks in the Semdinli and Eruh Districts. Since then, according to government data in 29 years of violent conflict, 22,120 (as of December 14, 2013) violent incidents have occurred due to both the PKK attacks and security force operations. ${ }^{17}$ Institutional datasets based on open sources (ISVG and STARTGTD) indicate that between 1984 and 2010, the PKK initiated nearly 2112 violent incidents that resulted in casualties and were reported in the media. ${ }^{18}$ The PKK conducted attacks in different forms and against different targets. The form of violent attacks included armed attacks, bombings, arson, assassinations, hostage taking, kidnappings, vandalism, and sabotage, while target status included security forces located in their respective military bases and outposts, and urban police stations and compounds, Provisional Village Guards (GKK), government staff (mayors, district governments, imams, teachers, etc.) and civilians (non-combatants).

As shown in Table 1, out of 38,982 casualties, nearly $39 \%$ were civilians (including government staff, which constitutes a very small portion) while $61 \%$ of casualties were security forces (soldiers, police and Provisional Village Guards). The percentages get close to each other when only the fatalities are considered; that is, nearly $53 \%$ of those killed belonged to security forces and $47 \%$ were non-combatant civilians in a total of 12,702 fatalities.

Directness of challenge This section breaks down the PKK violence into five different periods based on the nature of the violence as well as the PKK's strategies, and it analyzes these against the PKK's ontological factors. The sections below discuss each chronological period.

Figure 1 plots non-combatant civilian casualties (denoted with a dashed line) versus combatant security force casualties (with solid line) from 1984 (the outset of violence) to 2011. ${ }^{19}$ The proportions of combatant and non-combatant casualties indicate a changing trend. They slope toward and diverge from each other in various phases of the conflict. ${ }^{20}$ From 1985 to 1988 and from 1991 to 1993 , non-combatant casualties exceed combatant casualties, and they are almost equal in the rest of the period between

\footnotetext{
${ }^{17}$ Datasets reflect information on individual violent incidents (i.e., incident level data) including the variables of incident type (e.g., armed assault, bombing, arson, assassination, hostage taking, kidnapping, vandalism, sabotage, military operation, police operation), the date of incident, number of casualties/injuries (civilian, security personnel and government staff), target type, and the location of the incident. In institutional datasets, incident type reveals information on whether the violent incident occurred based upon a military strike or a violent attack initiated by the PKK that allows for singling out violent incidents initiated by the PKK and violent incidents subject to military counterinsurgency operations.

${ }^{18}$ Government datasets are centralized official datasets that include each violent incident regardless of whether it resulted in any casualties. For instance, there existed PKK attacks and raids to army outposts that did not result in casualties but there was a rural militant attack.

${ }^{19}$ Shaded areas in plotted figures refer to significant breaking points in PKK strategies in its entire (process of violent campaign 1984-2011) evolution.

${ }^{20}$ Non-combatant civilian casualties include killed and injured civilians including government staff, teachers, imams, mayors, district governors and etc., (as the result of PKK activities). Security force casualties include soldiers (including gendarmerie) and police forces.
} 
Table 1 Casualties due to the PKK conflict between 1984 and 2013

\begin{tabular}{|c|c|c|c|c|}
\hline & & Killed & Injured & Casualty \\
\hline \multirow[t]{5}{*}{ Security forces } & Military & 4989 & 11,440 & 16,429 \\
\hline & Police & 355 & 3502 & 3857 \\
\hline & GKK & 1420 & 2061 & 3481 \\
\hline & Total & 6764 & 17,003 & 23,767 \\
\hline & $\%$ Security force & $53.2 \%$ & $64.7 \%$ & $61.0 \%$ \\
\hline \multirow[t]{5}{*}{ Non-combatants } & Civilian & 5478 & 9277 & 14,755 \\
\hline & Teacher & 124 & 0 & 124 \\
\hline & Government staff & 336 & 0 & 336 \\
\hline & Total & 5938 & 9277 & 15,215 \\
\hline & $\%$ Civilian and Gov. staff & $46.8 \%$ & $35.3 \%$ & $39.0 \%$ \\
\hline \multirow[t]{3}{*}{ Total casualties } & & Killed & Injured & Casualty \\
\hline & & 12,702 & 26,280 & 38,982 \\
\hline & $\%$ total & $100 \%$ & $100 \%$ & $100 \%$ \\
\hline
\end{tabular}

1984 and 1993. This is mostly because the PKK attacks were on GKKs and their family members, including women and children.

First period 1984-1994 The PKK officially declared its guerilla war on August 15, 1984 with two attacks in the Semdinli and Eruh Districts in which one soldier was killed and 12 were injured, three of whom were civilians. Until 1994, when Ocalan acknowledged military defeat, this was considered to be a typical guerilla fight in which the PKK sought territorial control through physical extermination of the Turkish authority from the region [69]. However, in its initial years, PKK violence also reflected

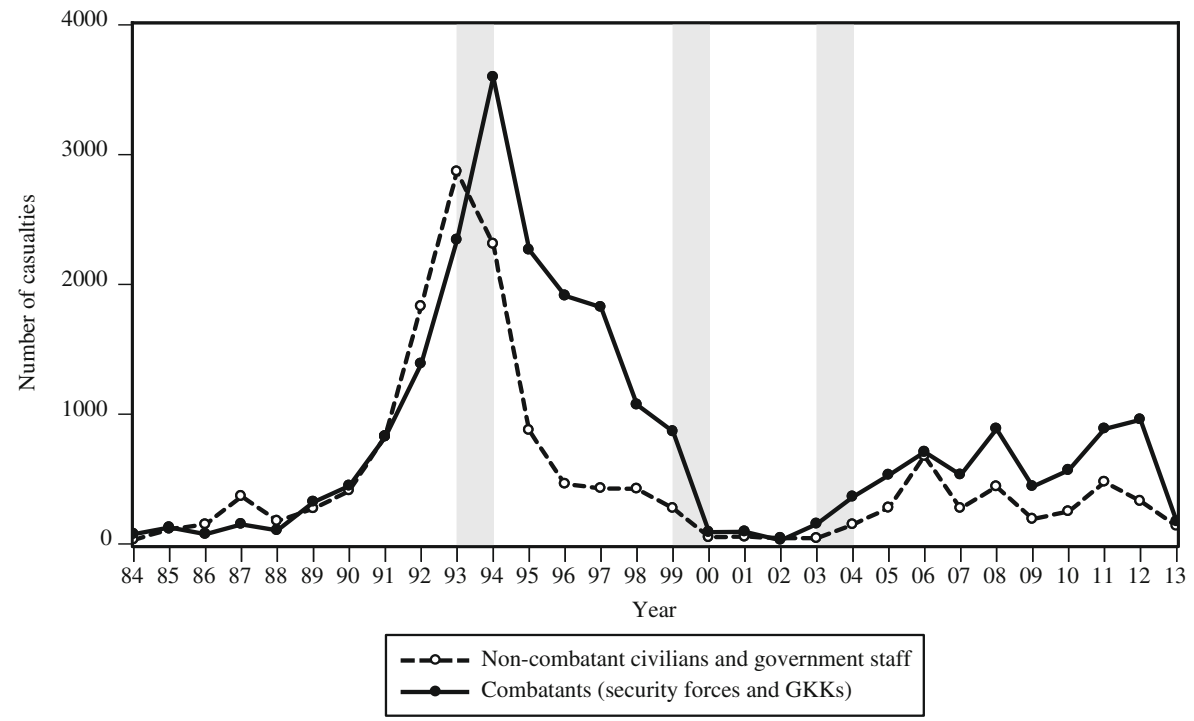

Fig. 1 Trend of non-combatant casualties vs. combatant (security force) casualties 
non-combatant targeting of Kurdish villagers. The southeastern region of Turkey (where the PKK claims independence) was highly feudal and underdeveloped in terms of education and economy. Ocalan, in his book titled "The Role of Force in KurdistanNational Independence Policy and War, 1982" stated that there is no other way but force to mobilize the public and put forth a "National Liberation Movement". The PKK strategically employed violence against non-compliant Kurdish inhabitants to enforce its mobilization from rural areas. To maintain the safety of remote villages against the PKK attacks ${ }^{21}$ and to counteract the PKK's initial Maoist Theory strategy, the government implemented the GKK system in 1985 and trained and armed volunteer Kurdish villagers against the PKK. The PKK declared GKKs as betrayers of Kurds and employed violence against GKKs and their family members as a result of its 3rd Congress in 1986. For example, in 1987 alone, the PKK carried out 15 different attacks in the region and killed 30 civilians, 16 of whom were children, and 8 of whom were GKK members in the Village of Pinarcik.

This period was marked by the PKK's use of indiscriminate violence based on Kalyvas' distinction in which targets are selected on the basis of their membership of certain groups (ethnicity, sectarian, religion, etc.) irrespective of their individual actions $[33,98]$. That is, GKK villagers and their families were subject to PKK attacks due to their support for government and non-compliance with the PKK. This has also happened in other civil wars, such as the Shining Path's killing numerous civilians for compliance in Peru. Such violence employed by the PKK conforms to Kalyvas' [33p.99] conception that violence in a civil war context for maintaining compliance is generally referred to as terrorism. As Findley and Young [19] argued, terrorism might be used in the eruption of a violent uprising to alert society and to change their beliefs toward a broader revolution. Yet, as Kydd and Walter [38] indicated, such violence is intimidation, one of the five different strategies of terrorism [38]. The violence peaks when the main goal is control and compliance, which is typical of the PKK conflict in those years.

The PKK's indiscriminate violence continued for government staff. ${ }^{22}$ PKK resolutions from its 2nd Conference in May 1990 and 4th Congress in December 1991 reflect the second stage of Maoist Theory, i.e., direct targeting and attrition of government authority in the region. To that end, from 1984 to 2000, the PKK killed government staff in the region and conducted 23 attacks against mayors and district governors in cities and villages, resulting in eight dead and three wounded. The PKK also killed 27 imams and 116 teachers. The aim of such terrorist strategy was attrition, as suggested by Kydd and Walter [38].

The PKK established its army (ARGK) in the 3rd Congress of October 1986 as a replacement for its individual attack units of HRK (Kurdistan Independence Unit). The PKK strove to out-fight the Turkish government in those years. The number and

\footnotetext{
${ }^{21}$ In order to maintain better control of the region and to reduce the PKK's flexibility and mobility, the Turkish Government established the Provisional Village Guard System (Gecici Koy Koruculugu Sistemi, GKK) in April 1985. Under the GKK system, the Turkish military trained and armed volunteer villagers to guard their residents and villages against the PKK militants.

${ }^{22}$ Indiscriminate violence does not necessarily mean to relate to terror attacks in the case of the PKK. The PKK conducted selected terror attacks just to reach specific periodical objectives in its struggle with Turkey. For example, the PKK conducted bombings in the western areas (touristic locations) to reduce Turkey's revenues extracted from tourism.
} 
location of violent incidents are plotted in Figs. 2 and 3 respectively. As shown in Fig. 2, the trend in violence steadily increases until 1994 due to intense fighting between the Turkish Army and the PKK. The epicenter of the fight was territorial during that period, and thus occurred in the southeastern region (emergency rule area) as indicated in Fig. 3. In 1994, Ocalan confessed that the PKK would need at least 50,000 guerilla units to take control of the region, defeat the Turkish Army, and win the war. The PKK had between 8000 and 11,000 armed militants at the time. ${ }^{23}$ With Ocalan's statement in the PKK's periodical (Serxwebun, Vol 148, April 1994), the PKK implicitly acknowledged its military defeat in 1994 [51]. The defeat was based on the Turkish Army's doctrinal change from "areal control" to "cordon and search", in which the former had resulted in remote army outposts becoming easy targets for the PKK. Based on the latter doctrine, however, the Turkish Army conducted large counterinsurgency operations with the support of land aviation units, which were effective in defeating the PKK on the battlefield. The PKK's military defeat after 10 years concurs with the Connable and Libicki's [12] argument that a typical insurgent fight in the confrontation phase lasts approximately 10 years and then it hits the tipping point.

Due to the military defeat, the PKK began to spread its violence more widely in order to reduce military pressure on its militants in the region. As seen in Fig. 3, violence starts to occur in non-emergency rule areas (dashed line in shaded area) in 1991 and the proportion of attacks shows an increase until 2000, namely, when the PKK declared a ceasefire due to Ocalan's capture in 1999. Carrying out attacks in nonemergency rule areas, which are not related to the PKK's aim, is considered to reflect indirectness of the fight.

The PKK, in this period, hoped to out-fight the Turkish Army, and its violence was directly linked to its goal of territorial secession using the Maoist strategy. The PKK also indiscriminately killed Kurdish GKK members and non-compliant Kurdish civilians with the purpose of intimidation, or used the threat of violence to achieve compliance. As Kalyvas [33] stated, such indiscriminate violence is considered to be terrorism; however, until 1994, PKK terror against Kurdish civilians was considered to be a tactic in its broader strategy of guerilla campaigns, designed to create a direct challenge. It reflects different reasoning and purpose, as Sambanis [58] and Findlay and Young (2012) argued, with overlapping nature within the context of the conflict.

That is, the PKK pursued its initial goal of territorial separation through direct challenge and elimination of direct obstacles (security forces, non-compliant Kurdish civilians and GKKs) in this period. In those years, the PKK strategy was based on a purely military modus operandi to create, through a top down approach, an autonomous Kurdish state. The PKK had a low opinion of political activities at that time and did not have a politico-military program. Due to his belief in military victory and his military focus Ocalan rejected any political affiliations with newly emerged pro-PKK political parties in the early 1990s.

Second period 1994-2000 Particularly after 1991, PKK violence started to vary in terms of its form and purpose reflecting an indirect challenge related to targets and locations irrelevant to its ontology. Starting in 1994, this became part of the PKK strategy. That is, resolutions from Congresses/Conferences held during this period

${ }^{23}$ Shaded areas in Fig. 2 denote the breaking points of PKK violence in the process of conflict. 


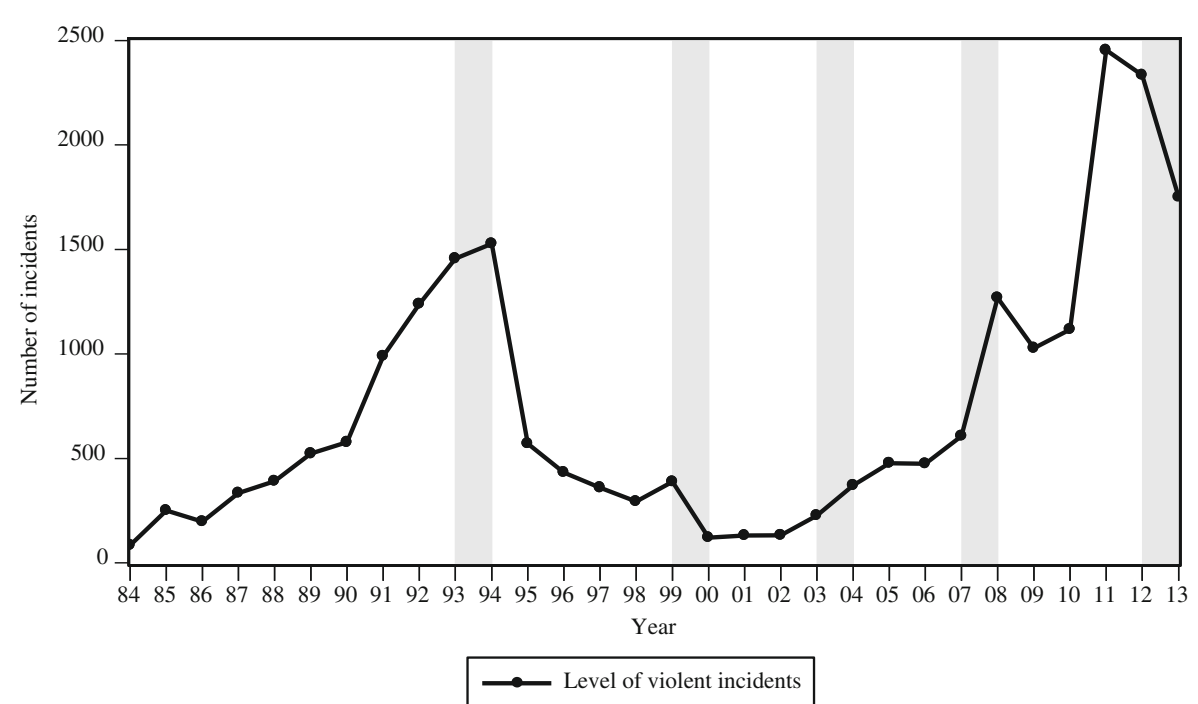

Fig. 2 Level of aggregate level violent incidents that occurred due to both PKK-initiated attacks and security force operations

(1994-1999) reflect the PKK's periodic strategy of spreading war from rural to urban areas and from PKK-related territories to the entire country. The PKK targeted economically significant places to disrupt the military presence in the region so they could regroup. ${ }^{24}$ The PKK started terror attacks such as bombings on non-combatant civilians in western metropolitan cities, targeting tourist locations, and public/private infrastructures such as oil pipelines, in addition to its protracted guerilla fight (resolution released at the 3rd Conference of May 1994). This is different from the terrorist strategy of intimidation targeting Kurdish civilians for compliance, which was also a direct obstacle for the PKK. This was more of a survival effort to redirect the Turkish counterinsurgency efforts away from the southeast region so that the PKK forces could recover.

The PKK's resort to terrorism (after 1994) for sustaining its campaign rather than fighting Turkish authority directly lasted until Ocalan's capture in 1999 (Ocalan had been expelled from Syria as a result of Turkey's military pressure with the Adana Agreement in 1998). As seen in Figs. 1 and 2, violent incidents and casualties were lower during this period compared with the pre-1994 term.

The Turkish State misconceived the PKK's military defeat and considered the war to be ending. They kept up repressive measures and their military campaign. However the fight has not ended for many reasons, one of which is that, as Lyall and Wilson [42] claimed, counterinsurgency (COIN) efforts, such as subjecting the uncommitted population to rewards and punishment with no critical information about the local population, do not have a chance of success. The Turkish Government's reliance on deterrence efforts (military and police operations) with an indiscriminate use of force unintentionally fueled the insurrection rather than deterring it $[67,68]$.

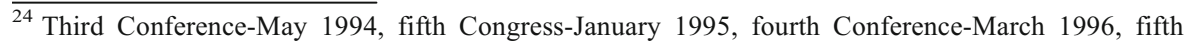
Conference-May 1988, and sixth Congress-February 1999.
} 


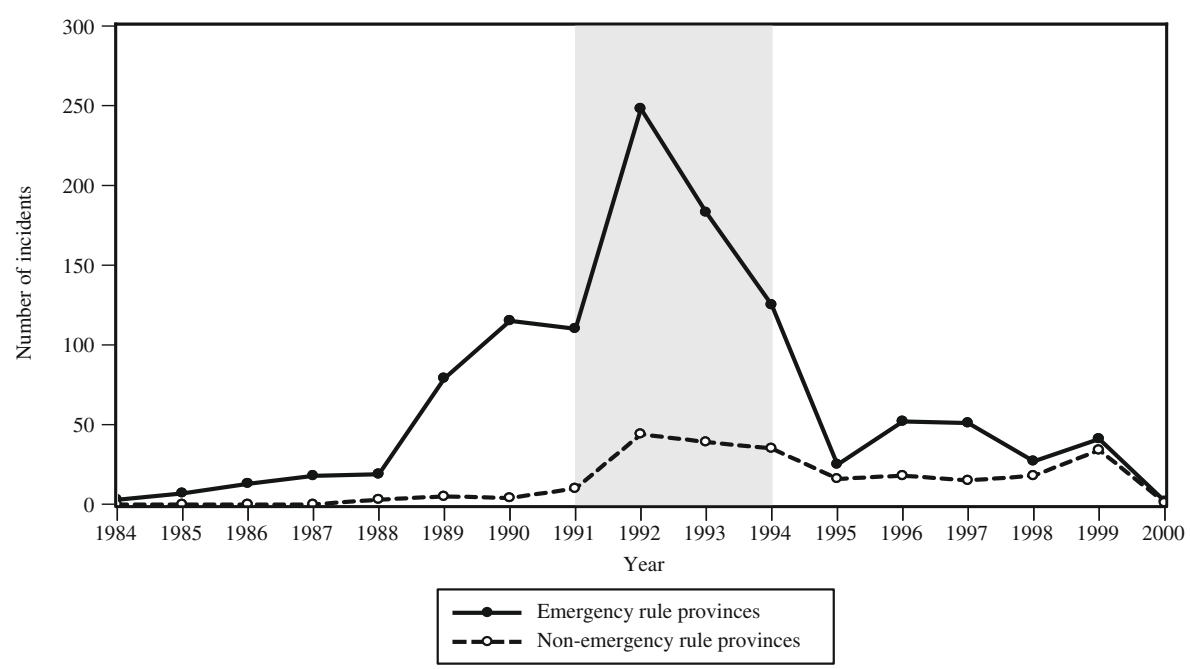

Fig. 3 Location of violent incidents, emergency rule provinces (southeastern provinces) vs. non-emergency rule provinces (1984-2000)

The major shift between the first (1984-1994) and the second (1994-2000) periods was that the PKK-initiated violence became more indiscriminate and indirect. While struggling to sustain a guerilla war in the southeast region, the PKK clearly relied on terror attacks in non-emergency rule areas against civilians to maintain its threat level and the weaken government authority.

Figure 4 plots bombings versus typical armed attacks. Bombings (dashed line) and armed assaults (solid line) slope toward each other beginning in 1994. As a mode of attack, bombings are more convenient in urban areas in comparison to typical insurgent raids. Some of these bombings were suicide attacks carried out mostly by female militants. As shown in Fig. 5, violent attacks targeting tourist locations show a dramatic

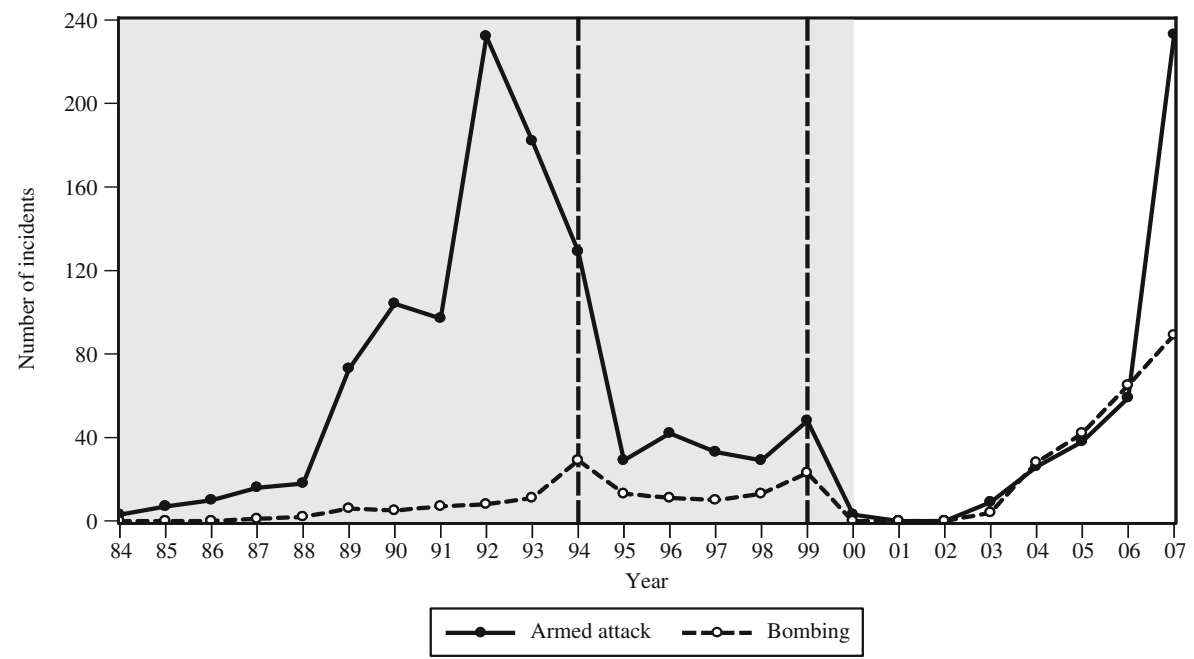

Fig. 4 The trend in mode of attack in PKK-initiated violent incidents; bombings vs. armed assaults (1984-2007) 


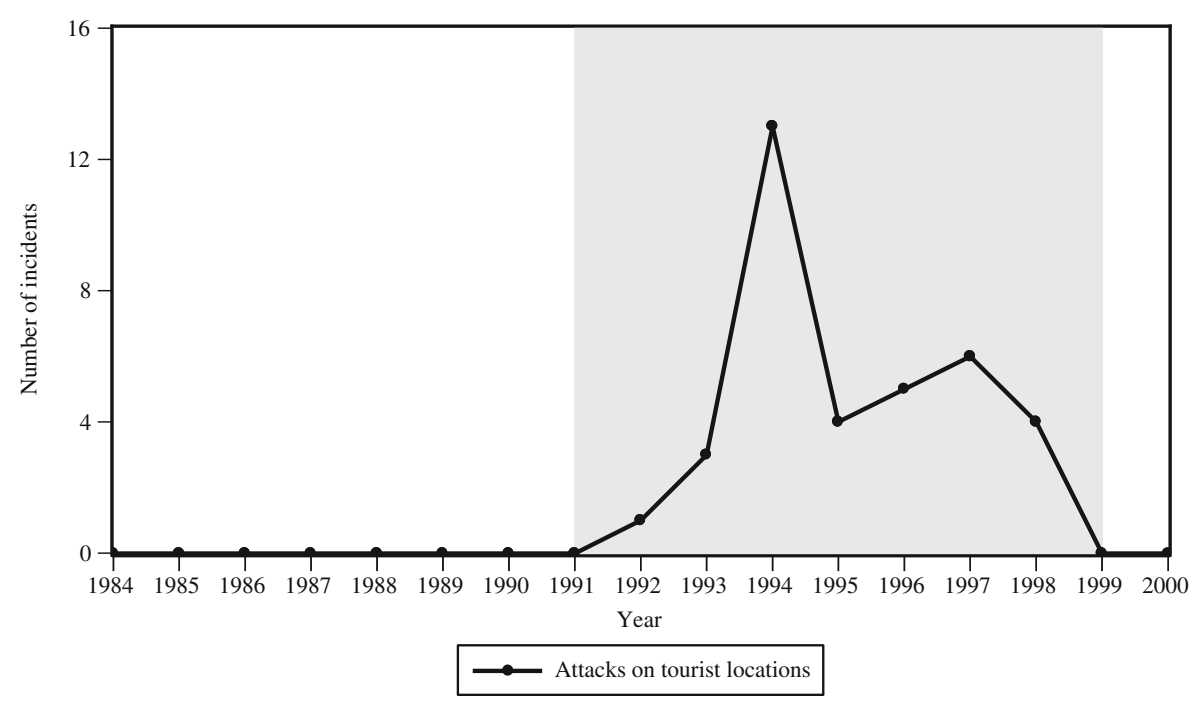

Fig. 5 Number of PKK-initiated violent attacks targeting tourist locations (1984-2000)

increase after 1991 until 1999 when Ocalan was captured and the PKK ultimately declared a unilateral (long-lasting) ceasefire [71].

Third period 2000-2004 In its 7th Congress held in 2000, the PKK revised its goal and strategy. The PKK stopped using violence, opting for politics over military efforts, and changed its goal from secession to official recognition of Kurdish identity in Turkey's Constitution, with all relevant political and cultural rights. To this end, the PKK abolished itself twice and respectively founded KADEK (Kurdistan's Independence and Democracy Congress) in its 8th Congress in 2002 and KONGRA-GEL (Kurdistan's People Congress) in its 9th Congress in 2003. The PKK ceased the violence with KADEK and denied violence with KONGRA-GEL. The PKK accelerated political and diplomatic activities around Europe to pressure Turkey to compromise and gain political representation and official recognition for Kurds in Turkey, but they were not successful. Beginning in 2002, countries such as USA, Canada, and Australia, and certain international bodies, e.g., European Union (EU) and United Nations, included the PKK on their list of terrorist organizations.

Fourth period 2004-2007 Subsequently, the PKK switched back to violence with a crucial difference. As opposed to its initial plan to move from rural to urban, the PKK conducted armed attacks and raids in a reactionary manner, to punish factions that questioned the ceasefire, establish solidarity among the members of the PKK, and provoke the Turkish Government to respond. The PKK relied heavily on domestic political efforts, in addition to keeping its campaign in the public eye through its reactionary guerilla attacks. As shown in Fig. 2, the aggregate level of violence indicates an increasing trend until 2008.

Despite the fact that PKK violence after its re-creation (declared in 11th Congress, 2005) was similar to the initial period of 1984-1991, the purpose of the violence was quite different. Contrary to Findley and Young [19], who categorized provocation as a 
strategic use of terrorism only in the pre-war term, PKK violence reflected Kydd and Walter's [38] categorization of provocation during this period of the conflict.

During this period, PKK violence showed a more asymmetrical and indirect character. Guerilla attacks were relatively more discriminate in nature, however for different purposes (provocation, solidarity), while certain rural attacks were in the context of terror toward civilians and even security forces in the non-emergency rule (irrelevant to PKK's goal) area. Overall PKK violence during this period reflected both indirect and direct and nature. It was indirect in terms of its purpose considering the ontological factors and it was direct in terms of its form and target status, with guerilla attacks targeting army outposts. In terms of reasoning, according to Kydd and Walter's [38] classification, the aim of PKK violence during this period was policy change, as opposed to territorial control (not change) from the initial period.

In this period (2004-2007), the PKK engaged in a process of political activity, and supportive military activity, as opposed to earlier periods. In this new period, the PKK aimed to become a political authority in the region through actions designed to diminish (out-administering) Turkish authority rather than out-fighting as it had in the past (1984-1994).

Fifth period 2007-2012 In 2007, Ocalan ordered the creation of the Union of Kurdistan Communities/Turkish Assembly, KCK/TM as an umbrella organization to lead the pro-PKK political agenda. In challenging Turkish authority, the PKK explicitly followed Ocalan's instructions issued through his periodic meetings with his attorney. The PKK, in this period, pursued a path to institutionalize and consolidate Ocalan's leadership and role in the conflict. For example, the PKK declared unilateral ceasefires as instructed by Ocalan (e.g., two main unilateral ceasefires, April 1999 to June 2010, and August 2010 to March 2011). Additionally, the PKK, through pro-PKK legal and illegal organizations, held public events and gatherings.

The PKK, with the creation of KCK/TM, first aimed to establish an alternative political authority. The KCK classified its organization as dealing with social, economic, political, ideological, and self-defense issues. For instance, for the ideological, the KCK established Political Academies to increase ethnic consciousness. For the social, it established educational support houses that taught certain elementary school classes in Kurdish language. All legal and illegal PKK functions and its affiliated groups operated under the KCK/TM umbrella.

Second, through a pro-PKK NGO, The Congress of Democratic Society (DTK), the PKK officially declared a de facto "Democratic Autonomy" in Diyarbakir on July 14, 2011. On the very same day and in the same province, the PKK killed 13 Turkish soldiers. Since then, PKK-related organizations struggled for social control through de facto practices in the social context until early 2013, when the Turkish government initiated a new era, the "peace/resolution process" ruled by the Justice and Development Party (AKP).

Violence during this period was highly strategic in the sense of provocation and attrition aiming at policy change and social control in the first stage, and then a regime change in the form of a self-governing local authority in southeastern region. The PKK conducted sensational guerilla attacks that were technically direct, but given that the purpose of these raids was to invoke social-political reaction, these attacks reflect more asymmetry and indirectness. 
This is also, as Crenshaw [13] argued, considered to be revolutionary terrorism and indicates the use of terrorism for revolutionary purposes in the context of insurgent uprisings. Yet, typical terror attacks targeting civilians, not for compliance but for invoking social reaction and fear, have also occurred. In order to portray such indirectness in this period, civilian casualties that occurred in the southeastern provinces are plotted against civilian casualties that occurred in western (non-PKK related areas) provinces in Fig. 6. The proportion of civilian casualties in western provinces is much higher than casualties in the east and southeast region in the 2004-2012 period. As discussed earlier, most civilian casualties in the pre-1994 period reflect the purpose of social mobilization through intimidation, as opposed to post-2004, when mostly civilian casualties occurred as indirect targets in the non-southeastern area for the purpose of pressuring the government into a political compromise.

Moreover, PKK violence reflects more strategic reasoning and selectivity, particularly after 2007. The PKK, for instance, employed selective violence toward police forces because it claimed that the high volume of recent KCK arrests (approximately 6000 in total) were part of the government's agenda put in place by the Police Academy and related political actors. As indicated in Fig. 7, police force casualties start to proportionately increase, exceeding soldier casualties in 2009-2011.

During this period, the PKK acted more in the context of a politico-military insurgency given its organizational functions in the social and political arenas; however, the legitimacy of PKK violence had been very low due to the use of bombings, kidnappings of civilians, teachers, prosecutors, and civil businessmen that rejected the PKK's extortion, off-duty members of the police and army; and intimidation in elections, both, national and local, to force people to vote for pro-

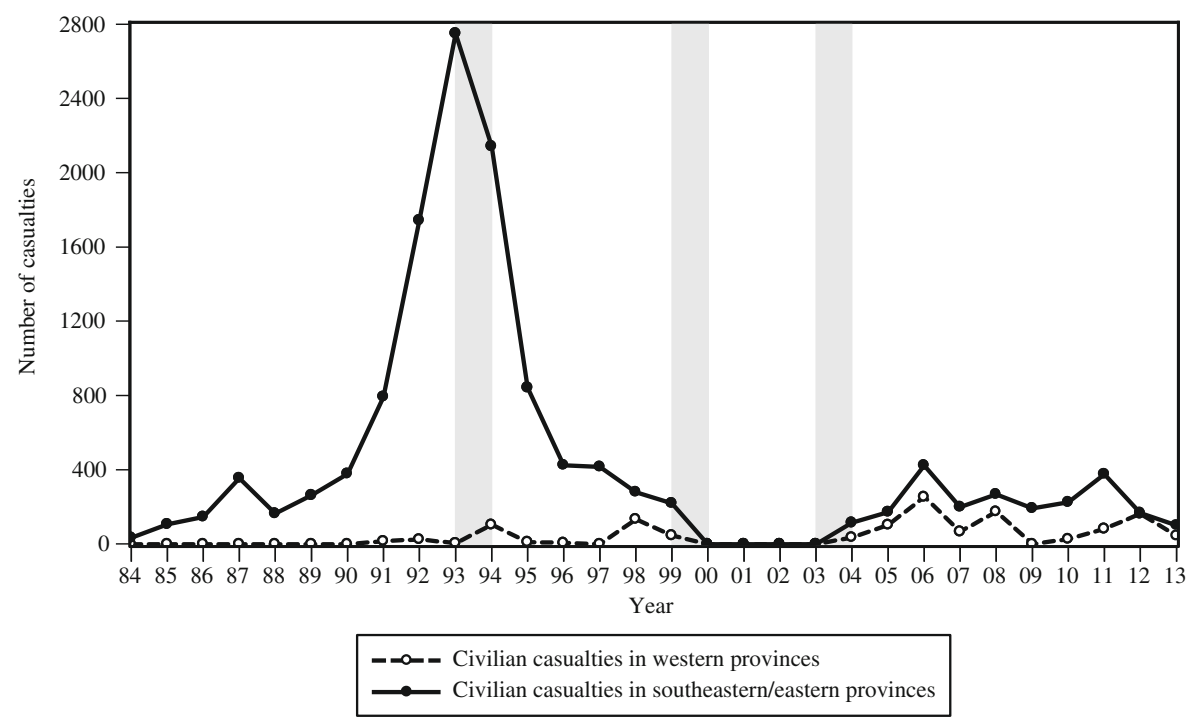

Fig. 6 Level of civilian casualties in PKK's goal related areas (24 provinces located in east and southeast Turkey) vs. level of casualties in western provinces (1984-2013) 


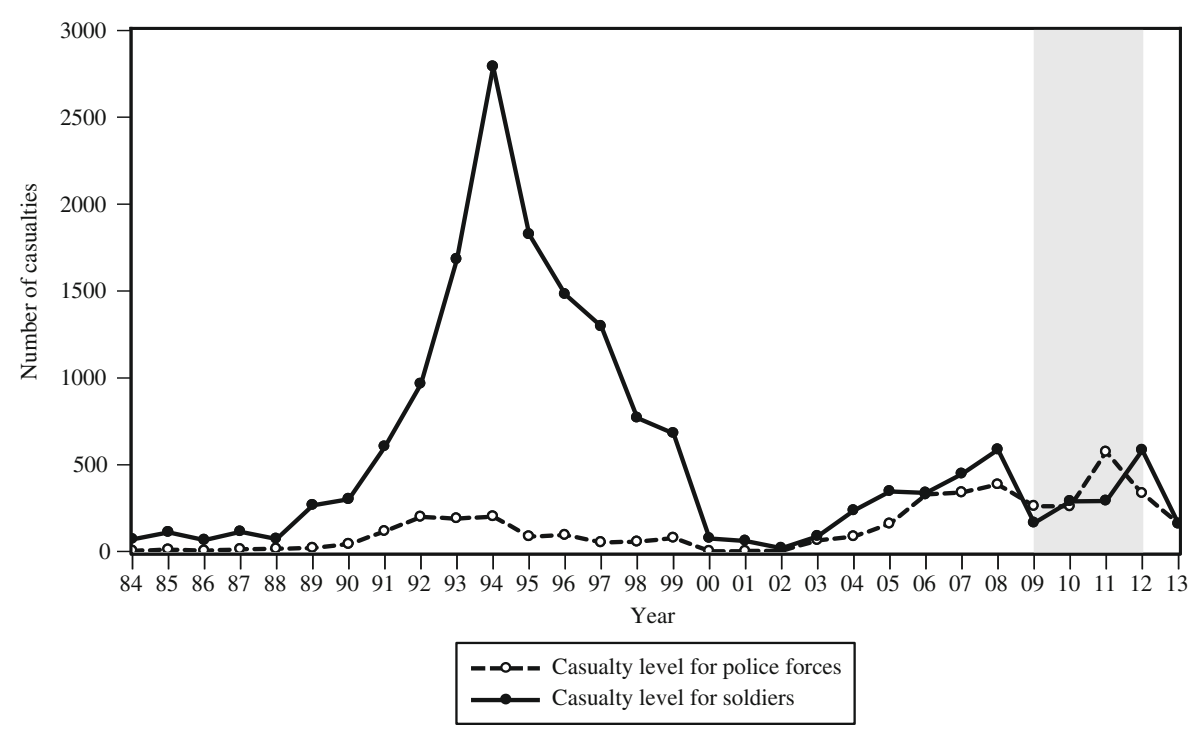

Fig. 7 Level of targeted police forces vs. security forces (1984-2013)

PKK candidates. $^{25}$ Figure 8 plots security force, civilian and total casualties for 1984-2013. Compared with the pre-1994 period, the PKK targeted security forces more than non-combatant civilians in 2007-2012 (shaded areas in Fig. 8). However, the purpose of violence and the nature of civilians were different than early terms of the conflict; the purpose was intimidation and compliance in the early years, but attrition during this period, which is indirectly linked to the PKK's ontological characteristics.

The PKK did insist on claiming legitimacy for its cause, mostly disregarding the illegitimacy of its acts. However, in the PIRA case, when civilian casualties occurred, PIRA took a defensive stance in its public statements to claim legitimacy around its use of violence [78]. The PKK used underground terrorist cells, e.g., TAK, and then denied ties to them. However, TAK is known to be the organization that conducted a number of terrorist attacks targeting civilians and security forces in urban areas of western provinces (non-PKK related regions).

The PKK in this period (2004-2007-2012) increasingly gave weight to the political side over the military and used the military side to coerce Turkey into a political compromise. In other words, rather than seeking a military defeat using a top-down approach, the PKK chose to try and diminish government control through a bottom-up approach in which violence was used in an indirect way with low legitimacy. In addition to the analysis of PKK violence from macro scale insurgent and terror attacks, illegal violent incidents at the micro scale also occurred. In recent years, for instance, while advocating the right to national education in Kurdish language (as the mother tongue), the PKK damaged 41 elementary schools, 27 of which were vandalized, and kidnapped 36 civilian workers and 26 teachers. The PKK also kidnapped local political

\footnotetext{
${ }^{25}$ Pro-PKK political parties participated in national elections with independent candidates with no official party affiliation due to the $10 \%$ threshold for political parties to make it to the Turkish Grand National Assembly.
} 


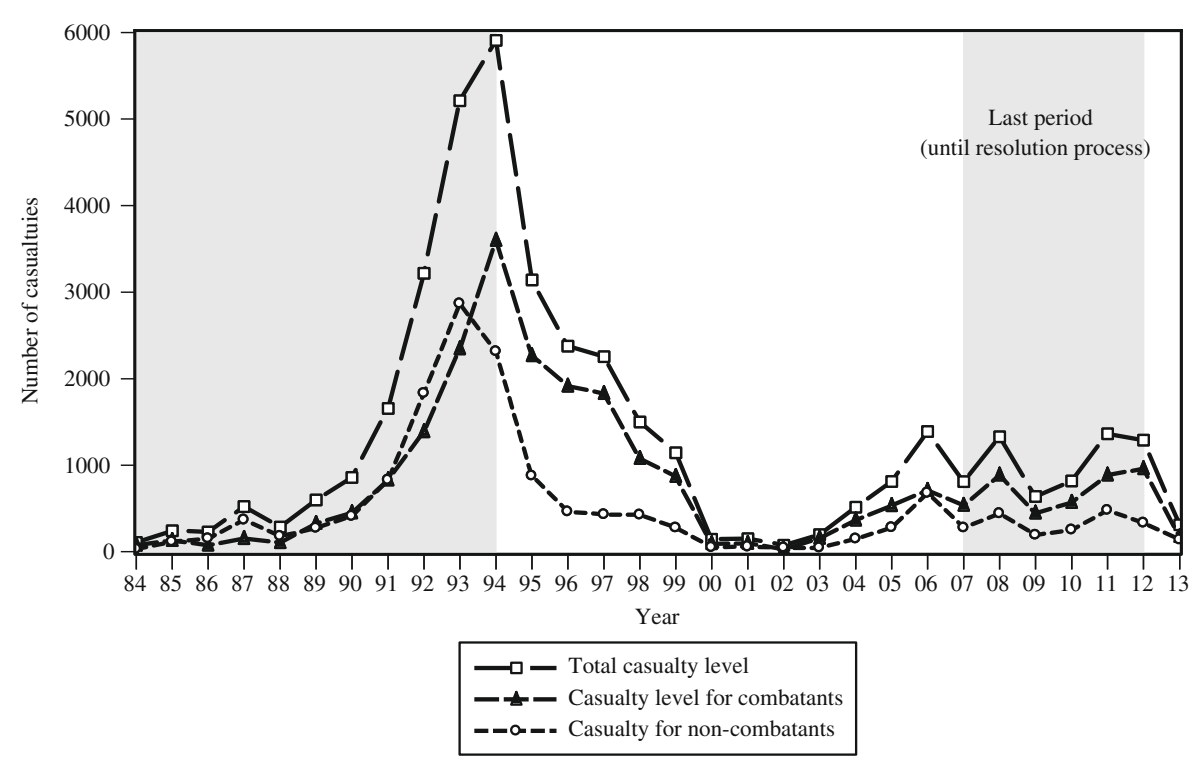

Fig. 8 Level of civilian and security force casualties vs. total casualties (1984-2013)

representatives from the ruling party AKP, headmen in villages, a doctor, GKK members, and security force members. Moreover, in hundreds of events, the PKK used adolescents under 18 in pro-PKK illegal public protests in which the adolescents threw stones and Molotov cocktails, vandalized vehicles, and conducted illegal checkpoints, particularly on the anniversary of Ocalan's capture in February and the PKK's declaration of war in September.

\section{Concluding remarks}

This study, by adopting a technical rather than a moralistic approach, analyzed the concepts of terrorism and insurgency by revisiting the discussions in the literature through the analysis and illustration of the PKK case. Analyses are based on multiple perspectives of actor-sense, action-sense (i.e., directness), and ontology-sense. The focus is on the action sense, with the entire span of the PKK conflict broken down to five different periods. The study then reviewed the form, nature and purpose of violence in terms of their linkage with the PKK's ontological factors. Based on the dynamics of the conflict, as well as the national and international context, this analysis found that the PKK shifted focus and direction to reach its overarching goal (over its periodic objectives) and periodically modified its goals and strategies. This is clearly reflected in the PKK's use of violence, particularly after their military defeat in 1994. The PKK employed different types of terrorism over different periods, as identified by Kydd and Walter's [38] five categories, as well as additional types outlined by Lyall and Wilson [42] and Stepanova [63, 10], that are defined as conflict-related terrorism.

With the inception of the fight in 1984, the PKK, in addition to typical guerilla warfare, used terrorism for intimidation to maintain the compliance of all Kurds, and targeted Kurdish villagers until 1996. Starting in the early 1990s, particularly after 
acknowledgement of their military defeat in 1994 and until Ocalan's capture in 1999, the PKK used terrorism as a part of its attrition strategy and for survival employing suicide attacks, explosive devices, etc. in western metropolitan cities. The group ceased the violence strategically until 2004 and shifted toward becoming an internationally recognized legitimate political entity through creation of KADEK in 2002 and KONGRA-GEL in 2003. However, these failed to gain legitimate status, and the PKK was officially listed as a terrorist organization by certain countries. The PKK recreated itself in 2005 and employed violence in a reactionary manner to gain popular support and regroup after the long-lasting ceasefire [68]. With the creation of KCK in 2007, the PKK switched to a bottom-up approach in which political activities took the lead. The PKK started to use more strategic violence in both terror and guerilla methods to maintain its place in the government's political agenda. To back its campaign for establishing de facto autonomy, the PKK heavily relied on its political campaign, which they named "Democratic Autonomy". In addition to sensational attacks on army outposts, the PKK, through its underground apparatus TAK, conducted terror attacks on civilians and security forces in non-PKK areas. The KCK cadres stationed in urban areas established PKK youth divisions i.e., the Movement of Compatriot Revolutionary Youth (YDG-H) for illegal activities. KCK members organized outlawed public events and conducted urbanized acts of violence in support of "Democratic Autonomy", which was declared on July 14, 2011 in Diyarbakir. To impose an alternate governing and political authority in the region, they conducted illegal checkpoints, underground judicial trials, etc.

The PKK has a highly insurgent character given its actor-based attributes that include organizational structure with recognizable management body, its direct military ways to challenge state authority, its specific goal(s), considerable level of popular support, and its recent use of non-violent activities in political, social, and economic realms. Nevertheless, violence employed by the PKK mostly reflects conflict-related/ revolutionary terrorism in addition to its insurgent attacks.

Figure 9 plots civilian casualties that occurred only in western provinces that are not related to the PKK's goal, and Fig. 10 portrays total civilian casualties in the entire country. As seen in Fig. 9, civilian casualties indirectly linked to the PKK cause and goal indicate a volatile but increasing trend (except for a higher blip in the fourth period) as opposed to total civilian casualties shown in Fig. 10, which indicate a parallel trend with the level of violence shown in Fig. 1. The civilian casualties are higher in the early years of the conflict due to the high volume of civilian casualties of noncompliant Kurds, which constituted direct obstacles to the PKK's goals.

This is because, contrary to a gradual process of political violence, which starts with terrorism and leads to guerilla and, if successful, to conventional warfare [40], the PKK's military evolution reflects the exact opposite. As Sambanis [58] claimed, it is difficult for terrorist groups to transform the conflict into a civil war. In the case of the PKK, terrorism has been and continues to be used as a strategy when conditions favor it. The PKK emerged as typical rural insurgency and pursued its goal of secession in a top-down approach directly and militarily challenging the state authority. However, subsequent to its military defeat, the PKK has given weight to political activities and switched to a guerilla campaign with strategic terrorist attacks in concert with its political agenda. In this, the PKK started to become more of a politico-military organization and relied more on political means, using its military activity as a 


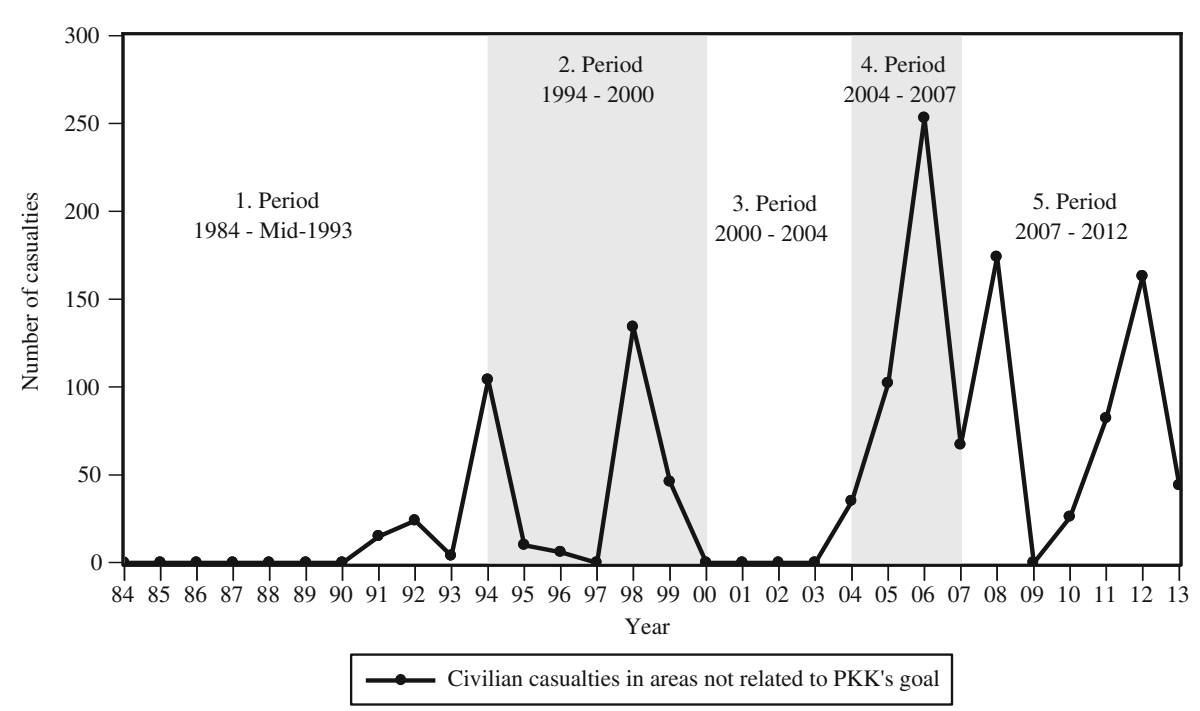

Fig. 9 Civilian casualties due to PKK violence in western provinces not relevant to the goal of the PKK

supplementary tool to reach its revised goal of "Democratic Autonomy". As plotted in Fig. 11, non-violent pro-PKK public events (organized by the PKK cadres) exceed violent incidents beginning in the early 1990s and the discrepancy increases as the conflict unfolds. This, again, indicates that the PKK adopted a political approach and used violence as an indirect complementary tool in its political campaign.

Overall, the PKK reflects an adaptive insurgent nature that strategically uses terrorism and guerilla attacks for its indirect periodic objectives (toward its overarching goal) since it acknowledged its failure to do so via direct military means. Its use of terrorism indicates additional categories to those suggested by Kydd and Walter [38]. These include the PKK's use of terrorism for survival (early 1990s until 1999) and solidarity

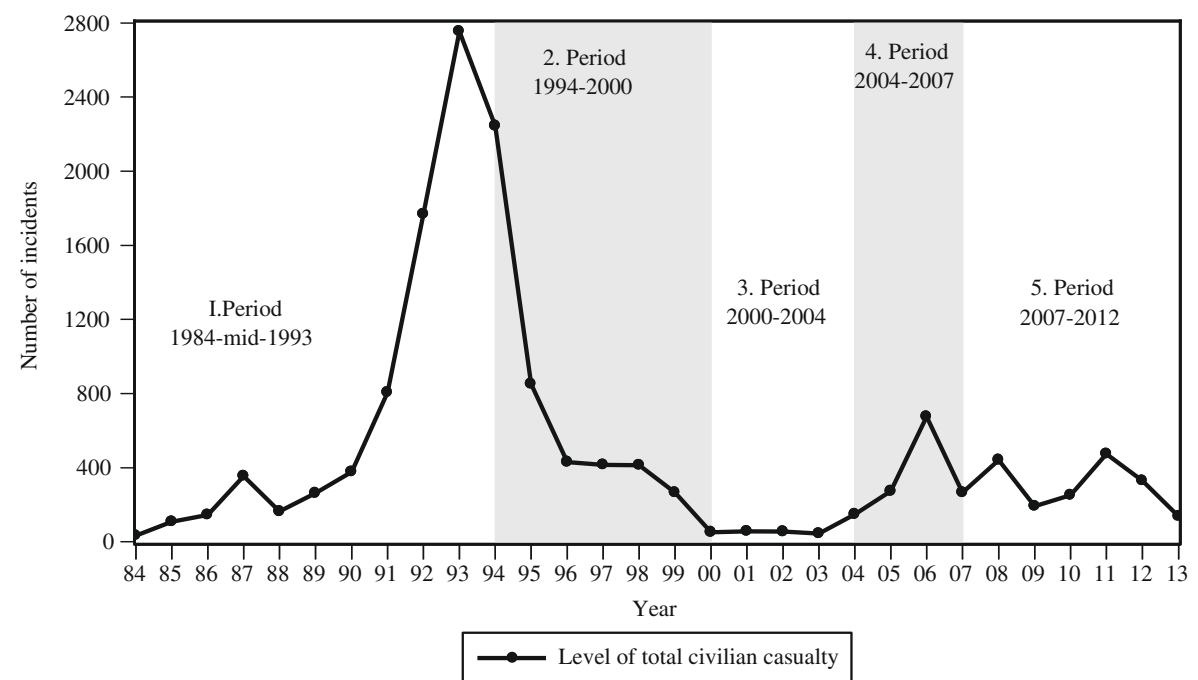

Fig. 10 Level of civilian casualties due to violence in the entire span of the PKK 


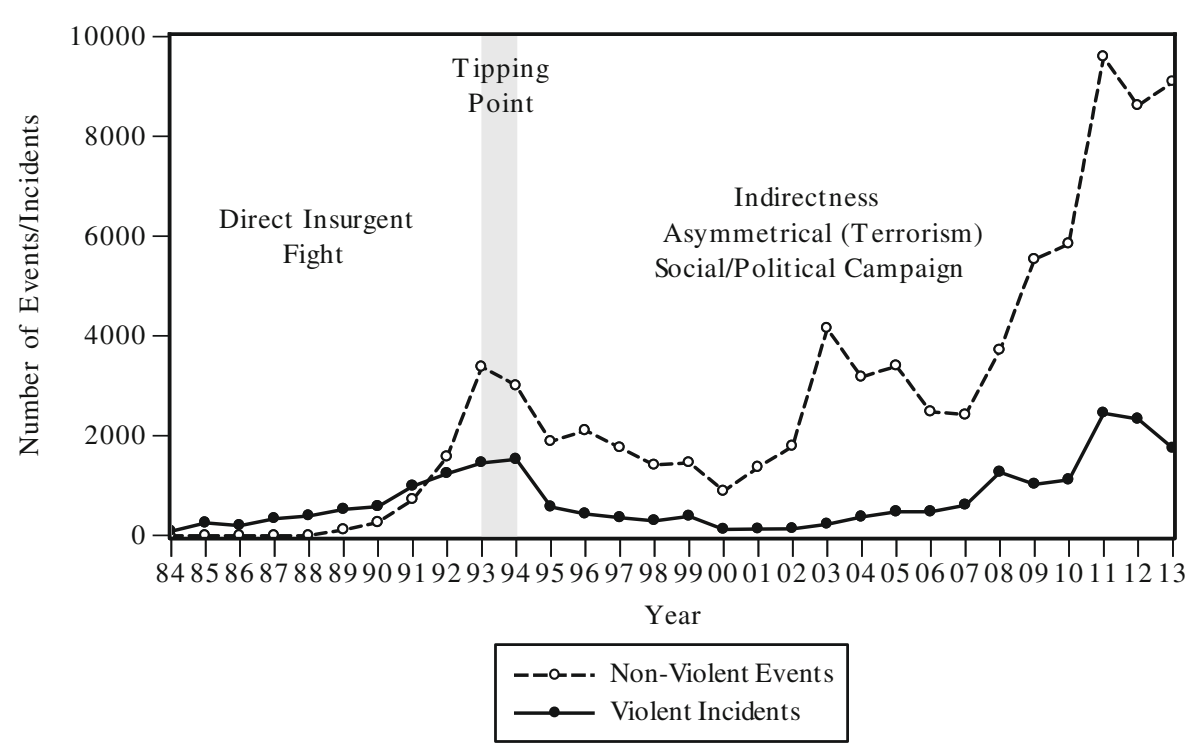

Fig. 11 Level of non-violent public events versus violent events due to the PKK conflict

up to 2007. The PKK also used other strategies, such as terrorism for intimidation (particularly in 1984-1996), attrition (1984-1999), and provocation (2003-2007). There also existed certain spoiling [terror] incidents, such as the killing of three proPKK women in France just after the outset of latest peace process, assassinating two ranked police officers, including the Deputy Chief of Police, and injuring the Bingol Chief of Police in October 2014.

In terms of the debate over whether terrorism is a strategy/tactic in the broader context of civil wars and insurgencies or strategy in its own right, the answer depends on the conceptual definition of terrorism and what type of terrorism is discussed. The PKK case, first, reflects a broader conflict in which the definition and type overlap to a great extent. Second, despite different reasons and factors, the use of terrorism is directly linked to a broader conflict with different purposes that are designed to meet interim objectives. Terrorist actions used during the PKK insurgency resulted from periodic strategies of intimidation, attrition, solidarity, survival, and provocation for the overlapping objectives of, respectively, territorial change, social control, policy change, and regime change as categorized in the literature [cf. 38]. Third, as to whether terrorism overlaps in the context of civil war or should be conceptualized outside of the civil war context due to its different reasons and factors, this analysis indicated more of the former as Stepanova [63] framed in conflictrelated terrorism. That is, although the reasons and factors for PKK terror might differ for interim objectives, it is linked to and overlaps with other forms of political violence in the context of the broader conflict. Thus, there exist linkages and close relationships between different forms of terrorist and insurgent actions, given their strategic objectives and the PKK's overarching goal(s). From an actor-based, the PKK embraced terrorism and through allegedly 
separate groups, e.g., TAK, employed typical terrorist attacks against civilians (mostly in urban areas).

Finally, the PKK's use of terrorism indicates direct efforts to realize its objectives and indirectness toward its ontological factors of overarching goal(s), declared causes and grievances. This infers an indirectness that underlines differences between a terrorism employed by a terrorist group and terrorism used as a strategy by a characteristically insurgent group in the case of the PKK.

The reasons why the PKK has resorted to more indirectness in methods and strategies, particularly after its military defeat in 1994, are related to certain major issues in theories of insurgency in the context of an intra-state civil war. In that, the PKK reflects Kalyvas's [32] new context of civil war with multiple varying forms of terrorism and organized crime for financing, as opposed to "old" civil wars with more direct and legitimate use of violence and less criminal activity. PKK's strategies of violence, however, are related more to the methods used in post-Maoist approaches. In that, the PKK, having acknowledged military defeat in the conventional sense in 1994, has been pursuing strategies to help the inferior power prevail as (Areguin-Toft 2001) and closely related to Mao's theory. Paraphrased, the PKK relied on indirectness - in its strategic interaction-aimed at reducing the power advantage of the Turkish State by attempting to destroy the latter's will to fight rather than its capacity. In addition, the state's relative power, as argued by Mack [43], results in less resolution because the state is more politically vulnerable due to a frustrated public and competing ideas about how to end such insurgent violence. This has been the case of the Turkish State's efforts to deal with the PKK through the early 2000s and particularly since 2007.

Policy implications When a soldier or civilian is killed by a violent group, does it matter whether terrorism or insurgency was behind the violence? In fact, distinguishing terrorism from insurgency is not just an academic enterprise. How the government classifies and recognizes violence determines the government's official countermeasures to the perceived problem. Most importantly, governmental strategies based upon such recognition might determine the potential transformation of that violent opposition into a peaceful political dissent or a prolonged violent civil war. In general, the real difference between terrorism and insurgency becomes clear when considering this potential. Terrorism by nature cannot generate mass-level support from the populace as much as insurgents can. This is the point when governmental strategies and countermeasures play a key role. Poor management approaches that disregard grievances and root causes related to the opposition might yield counterproductive policies for tackling a violent opposition. Hard line securitization policies that are not attentive to the social and political side of the phenomenon can facilitate the escalation of terrorism into civil war. This is when the perceptual legitimacy related to popular support that is influenced by governmental actions comes into play. It is essential for any state to select an appropriate combination of political, legal, bureaucratic, and organizational measures, as well as a compelling and accommodative narrative in official communications. For instance, the state's use of coercive force as well as soft power should be in a context that focuses on right targets, and should not be greater than necessary in its magnitude, i.e., proportional [cf. 47]. This is important to reduce and control the risk of escalation from terrorism into civil war. 
There is a link between how states perceive violent opposition and how they respond to it. This link between the threat perception and the conception of governmental efforts makes such distinctions a prominent issue. In that, the identification of typical terrorism versus terrorism that is part of an insurgent strategy is particularly important. Labeling a violent group, either in its own territory or in another country, as terrorist or insurgent is a deliberate political action that has significant political, legal, social, military and economic ramifications.

Over the last two decades, the traditional historical distinctions between terrorism and insurgency have been blurred to a great degree. This is mostly because there is a trend toward the increased use of terror as the easiest and the most rationale mode of struggle given its cost-effective nature within insurgent campaigns. By the same token, the line between counterterrorism (CT) and counterinsurgency (COIN) has become fuzzy, with significant implications. The already difficult job of determining and employing the right magnitude of force and doing it in the right context is complicated further. Most states make a choice to intertwine terrorism and insurgency, not because of intellectual carelessness but as a deliberate choice; i.e., using terrorism jargon for both. However, the use of terror by a non-state actor does not make the situation a mere terrorism issue. The legitimacy of governmental countermeasures and their direct impact on popular support make such distinctions crucial [68]. Since COIN is more of a political and socio-economic phenomenon, it is important to have a compelling and consistent narrative communicated via appropriate means as the state implements fitting policies [15]. It is not unusual for perception and sympathy to precede the actual policies on the ground. History shows that demonizing, humiliating and patronizing the opposing group results in counterproductive consequences for the state. The lack of a well-crafted communication strategy and the dissemination of derogatory messages by different governmental actors can only worsen the situation.

Such distinctions are also critical from a foreign policy perspective. The way a state officially labels a violent opposition in another country has certain moral, legal and emotional consequences. The well-known dictum, “one man's terrorist is another man's freedom fighter," brings up an equally political and ideological issue. In this sense, becoming involved in a national liberation insurrection in another country has been politically risky for third parties due to the lack of an officially accepted workable definition of terrorism in the international community.

Although the PKK started as an insurgency and concurrently employed terror, deep-rooted historical grievances and regional instability have sustained the insurrection. The government's counterterrorism and securitization actions did not consider popular support for the PKK until the early 2000s [68]. During the entire span of the PKK conflict, the Turkish government has obfuscated the true meanings of the terms terrorism and insurgency. Intentionally choosing the former, the government labeled and stigmatized the PKK as a terrorist organization and, for many years, officially treated the PKK solely as a terrorism problem. Subsequently, Turkey implemented intense securitization policies with no policy response to the legitimate grievances related to the Kurdish opposition led by the PKK, despite certain premature and weak attempts to approach the issue from a conflict resolution perspective; e.g., President Ozal's resolution attempt in 1993. Focused on the action-oriented characteristics, the government applied only counterterrorism measures to mitigate violence, labeling 
PKK actions as terrorism to delegitimize the PKK as well as legitimizing the state's use of force.

Turkey employed repressive measures and military action, along with emergency statements and special criminal justice tools, to bypass the regular civilian rule of law until the 2000s. However, in ethnicity-related identity conflicts, countermeasures, particularly the use of military force, have impacted more than just the level of violence. Such countermeasures also have unintended consequences for the popular support for violent opposition and ethnic/national consciousness. In most cases, the use of force is counterproductive in the long run. Use of excessive military action has collateral damage on civilian populations, such as the forced evacuation of villages during the PKK conflict in Turkey. Only after the early 2000s, did Turkey start to shift from an enemy-centric approach to a population-centric approach, and adopted certain policies to address legitimate grievances. Turkey did not recognize the PKK's insurgent nature and neglected the popular support behind it. Respective governments' shortsighted and populist policy choices have strengthened the PKK in the social and political arenas despite its military defeat. This is considered - amongst others - one of the important reasons behind the longevity and sustainability of the PKK insurrection. Official state discourses have continued to involve harsh terrorism jargon in varying scales, even when the government engaged in resolution attempts (2007-2011 and 2013-2015).

From an ex-ante, preemptive perspective, understanding the actor-oriented characteristics of a violent opposition, along with various types of terrorism and guerilla insurgent attacks and their relationship to one another, is crucial. In the end, the whole struggle revolves around gaining legitimacy through obtaining the necessary popular support (and denying it to one's opponent). Because it is a zero-sum commodity, a gain in the government's perceived legitimacy means a loss for the opposition group. So, the struggle between the two is composed of competing political campaigns to influence public support. Given that the use of force and the existence of violence create an unstable equilibrium, such an unpredictable environment makes day-to-day decision making extremely difficult. For that reason, affected states need a clear understanding of the problem at stake coupled with a realistic and flexible counterstrategy (that would include not only a military approach, but above all, a political one, too) that can break this vicious cycle to undermine the strategy of its opponent. In this regard, careful and realistic analysis of the characteristics of a conflict is necessary for states to develop successful and constructive policies and strategies.

From an ex-post, reactive view, selecting the right technical strategies requires identifying and understanding the nature, form, and the purpose of violence and how these relate to the opposition group's periodic objectives and overarching goals. So, again, determining the nature of the problem is crucial to developing necessary measures and prospective solutions. Finding the delicate balance between deterrence/ securitization and accommodative/responsive policies among counterterrorism, counterinsurgency or conflict management/resolution is sine quo non for states facing a violent uprising [67].

From a policy perspective, understanding the positive and negative impacts of policies that have been implemented is equally important for policy makers. Data on terrorist and insurgent groups shows that terrorist groups are doomed to fail or become marginalized over the course of time (i.e., roughly in 20 years - four waves of terrorism) unless they evolve into an insurgency. Yet, an insurgency that exploit 
grievances related to issues such as ethnic background, enjoys safe havens either in cities or in rural areas, possesses adaptation skills, uses strategic communication, and faces excessive but weakly concerted coercive power. It, thus, stands a strong chance of achieving its political goals. Policymakers need an accurate understanding of the ontology and nature of the opposing party in order to find the least costly way to end the violence, and develop their long run strategy in line with this end-state projection.

In this regard, it is important to understand what the PKK strategically did to coerce Turkey into a political concession to reach its goal via negotiated settlement. As analyzed throughout the study, once the PKK acknowledge its military defeat through a direct challenge, the group shifted to indirect means that increasingly included terrorism. The stalemate here is not in defeating the PKK on the battlefield (for a territorial control), but in marginalizing the PKK induced violence. Turkey's efforts did not minimize the violence and the PKK has maintained the ability to employ violence throughout the conflict. This, inter alia, has led the Turkish government to recognize the stalemate and engage in resolution processes (two attempts since 2007) aimed at a negotiated settlement that the PKK has been seeking since 1993.

This study recommends that states, in their countermeasures, give particular attention to the actor-oriented characteristics when determining the overall state strategy to control the problem (as Sun Tzu would suggest, one has to know one's enemy). Unlike terrorist campaigns, insurgent campaigns relate more to sociopolitical activism targeting a particular segment of populace. COIN campaigns should be designed more broadly rather than securitization efforts focusing only on action-oriented characteristics. More specifically, as opposed to CT, which is broadly categorized as deterrence, use of civilian law, enhanced defenses and negotiation policies. COIN, however, includes political, military and paramilitary, economic, psychological and civic actions in addition to those CT categories. While CT and COIN overlap, what critically differs the two is that the COIN campaigns cover more of the political and social spheres. Despite the changing and evolving doctrines, $\mathrm{CT}$ and COIN are in essence two fundamentally different but interrelated concepts, each having strengths and weaknesses on different levels. Understanding these strengths and weaknesses is critically important for states to appreciate their use in a given context when confronting forms of political violence. In this lies the art of strategy.

\section{References}

1. Akturk, S. (2011). Regimes of ethnicity: comparative analysis of Germany, the Soviet Union/Post-Soviet Russia, and Turkey. World Politics, 63(01), 115-164.

2. Alexander, Y., Brenner, E. H., \& Krause, S. T. (Eds.). (2008). Turkey: Terrorism, civil rights, and the European Union. Routledge.

3. Ankara Papers (2004). The case of the PKK: history, ideology, methodology, and structure (1978-99). $9(1), 55-6$.

4. Arreguin-Toft, I. (2001). How the weak win wars: a theory of asymmetric conflict. International Security, 26(1), 93-128.

5. Arreguín-Toft, I. (2012). Contemporary asymmetric conflict theory in historical perspective. Terrorism and Political Violence, 24(4), 635-657. 
6. Bal, I., \& Ozkan, E. (2006). Dunyada Onemli Olaylar Kronolojisi - PKK Teror Orgutu Kronolojisi (19762006). Uluslararasi Stratejik Arastirmalar Kurumu USAK. http://www.usak.org.tr/dosyalar/dergi/ z6UFq2LoFkdiuzBbZSt9qHMi7u4Ke2.pdf. Accessed 01 July 2014.

7. Barber, B. R. (2007). Terror is inescapably contestable. World Policy Journal, 24(1), 55-56.

8. Barkey, H. J., \& Fuller, G. E. (1997). Turkey's Kurdish question: Critical turning points and missed opportunities. The Middle East Journal, 59-79.

9. Belge, C. (2011). State building and the limits of legibility: kinship networks and Kurdish resistance in Turkey. International Journal of Middle East Studies, 43(01), 95-114.

10. Collier, P., \& Hoeffler, A. (2004). Greed and grievance in civil war. Oxford Economic Papers, 56(4), 563595.

11. Collier, P., Hoeffler, A., \& Rohner, D. (2009). Beyond greed and grievance: feasibility and civil war. Oxford Economic Papers, 61(1), 1-27.

12. Connable, B., \& Libicki, M. C. (2010). How insurgencies end (Vol. 965). Rand Corporation.

13. Crenshaw, M. (Ed.). (2010). Terrorism in context. Penn State Press.

14. Crenshaw-Hutchinson, M. (1972). The concept of revolutionary terrorism. Journal of Conflict Resolution, 383-396.

15. Department of the Army. (2006). U.S. army and marine corps Field Manual (FM) 3-25 counterinsurgency. Washington D.C.: Department of Defense.

16. Ergil, D. (2000). The Kurdish question in Turkey. Journal of Democracy, 11(3), 122-135.

17. Fearon, J. D. (2008). Economic development, insurgency, and civil war. Institutions and Economic Performance, 292-328.

18. Fearon, J. D., \& Laitin, D. D. (2003). Ethnicity, insurgency, and civil war. The American Political Science Review, 97(01), 75-90.

19. Findley, M. G., \& Young, J. K. (2012). Terrorism and civil war: a spatial and temporal approach to a conceptual problem. Perspectives on Politics, 10(02), 285-305.

20. Frisch, E. (2012). Insurgencies are organizations too: organizational structure and the effectiveness of insurgent strategy. The Peace and Conflict Review, 6, 1-23.

21. Galula, D. (2006). Counterinsurgency warfare: Theory and practice. Greenwood Publishing Group.

22. Ganor, B. (2002). Defining terrorism: is one man's terrorist another man's freedom fighter? Police Practice and Research, 3(4), 287-304.

23. Gibbs, J. P. (1989). Conceptualization of terrorism. American Sociological Review, 329-340.

24. Golder, B., \& Williams, G. (2004). What is“ Terrorism'? Problems of legal definition. University of NSW Law Journal, 27(2), 270-295.

25. Goodwin, J. (2006). A theory of categorical terrorism. Social Forces, 84(4), 2027-2046.

26. Gurr, T. R. (1970). Why men rebel. Princeton, PUP.

27. Harmon, C. C. (2001). Five strategies of terrorism. Small Wars and Insurgencies, 12(3), 39-66.

28. Horowitz, D. L. (1985). Ethnic groups in conflict. University of California Press.

29. Huntington, S. P. (1993). The clash of civilizations?. Foreign Affairs, 22-49.

30. Joes, A. J. (2006). Resisting rebellion: The history and politics of counterinsurgency. University Press of Kentucky.

31. Jones, C., \& Pedahzur, A. (Eds.). (2013). Between terrorism and civil war: The Al-Aqsa Intifada. Routledge.

32. Kalyvas, S. N. (2001). "New" and "old" civil wars: a valid distinction? World Politics, 54(01), 99-118.

33. Kalyvas, S. N. (2004). The paradox of terrorism in civil war. The Journal of Ethics, 8(1), 97-138.

34. Kiras, J. D. (2007). Irregular warfare: Terrorism and insurgency. Understanding Modern Warfare, 224.

35. Kirisci, K., \& Winrow, G. (1997). The Kurdish question and turkey. London: Frank Cass.

36. Kocher, M. (2007). The decline of PKK and the viability of a one-state solution in Turkey. Democracy and Human Rights in Multicultural Societies, 93.

37. Krueger, A. B., \& Laitin, D. D. (2008). Kto Kogo?: a cross-country study of the origins and targets of terrorism. Terrorism, economic development, and political openness, 148-173.

38. Kydd, A. H., \& Walter, B. F. (2006). The strategies of terrorism. International Security, 31(1), 49-80.

39. Laciner, S., \& Bal, I. (2004). The ideological and historical roots of the Kurdist movements in Turkey: ethnicity, demography, and politics. Nationalism and Ethnic Politics, 10(3), 473-504.

40. Lai, B., \& Larsen, K. (2008). Examining the escalation of terrorist violence to civil war. Bepress

41. Lomperis, T. J. (1996). From people's war to people's rule: Insurgency, intervention, and the lessons of Vietnam (pp. 1945-95). University of North Carolina Press.

42. Lyall, J., \& Wilson, I. (2009). Rage against the machines: explaining outcomes in counterinsurgency wars. International Organization, 63(01), 67-106. 
43. Mack, A. (1975). Why big nations lose small wars: the politics of asymmetric conflict. World Politics, 27(02), 175-200.

44. Marcus, A. (2007). Blood and belief: The PKK and the Kurdish fight for independence. New York University Press.

45. McCormick, G. H., \& Giordano, F. (2007). Things come together: symbolic violence and guerrilla mobilisation. Third World Quarterly, 28(2), 295-320.

46. Merari, A. (1993). Terrorism as a strategy of Insurgency. Terrorism and Political Violence, 5(4), $213-251$.

47. Miron, M. (2015). Terrorism. In B. Deane-Peter (ed.), Key concepts in military ethics (pp. 179184). University of New South Wales Press.

48. Moynihan, D. P. (1993). Pandaemonium: Ethnicity in international politics. Oxford University Press.

49. Nagl, J. A., Amos, J. F., Sewall, S., \& Petraeus, D. H. (2008). The US Army/Marine Corps counterinsurgency field manual (No. 3-24). University of Chicago Press.

50. O’Neill, B. (2001). Insurgency and terrorism: Inside modern revolutionary warfare. Herndon, VA: Brassley's Inc.

51. Ocalan, A. (1994). Commentary "Newroz kahramanlık șehitlerimiz bahar hamlemize öncülük ediyor. Serxwebun. 148-1, p.1. http://www.serxwebun.org/arsiv/148/. Accessed 12 May 2014

52. Ramraj, V. V. (2006). Counter-terrorism policy and minority alienation: some lessons from Northern Ireland. Singapore Journal of Legal Studies, 385-404.

53. Ramraj, V. V., Hor, M., \& Roach, K. (Eds.). (2005). Global anti-terrorism law and policy. Cambridge University Press.

54. Rapoport, D. C. (2004). The four waves of modern terrorism. In Attacking terrorism: Elements of a grand strategy (pp. 46-73).

55. Rich, P. (1984). Insurgency, terrorism and the apartheid system in South Africa. Political Studies, 32(1), 68-85.

56. Roth, M. P., \& Sever, M. (2007). The Kurdish Workers Party (PKK) as criminal syndicate: funding terrorism through organized crime, a case study. Studies in Conflict \& Terrorism, 30(10), 901-920.

57. Sambanis, N. (2004). Using case studies to expand economic models of civil war. Perspectives on Politics, 2(02), 259-279.

58. Sambanis, N. (2008). Terrorism and civil war. In P. Keefer and N. Loayza, (Ed.). Terrorism, economic development, and political openness. Cambridge University Press.

59. Sánchez-Cuenca, I., \& De la Calle, L. (2009). Domestic terrorism: the hidden side of political violence. Annual Review of Political Science, 12, 31-49.

60. Saul, B. (2005). Definition of "terrorism" in the UN Security Council: 1985-2004. Chinese Journal of International Law, 4(1), 141-166.

61. Schmid, A. (2004). Terrorism-the definitional problem. Case Western Reserve Journal of International Law, 36, 375-382.

62. Simsek, Y. (2006). Impact of terrorism on migration patterns in Turkey (Ph.D. Dissertation). Virginia Commonwealth University, Richmond, Virginia.https://digarchive.library.vcu.edu/bitstream/handle/ 10156/1311/simseky_phd.pdf?sequence=1. Accessed 05 Aug 2014.

63. Stepanova, E. A. (2008). Terrorism in asymmetrical conflict: Ideological and structural aspects (No. 23). Oxford University Press.

64. Taydas, Z., Peksen, D., \& James, P. (2010). Why do civil wars occur? Understanding the importance of institutional quality. Civil Wars, 12(3), 195-217.

65. Terrorism Research, resource document (n.d.). http://www.terrorism-research.com/insurgency/. Accessed 01 July 2014.

66. Tilly, C. (2004). Terror, terrorism, terrorists. Sociological Theory, 22(1), 5-13.

67. Unal, M. C. (2011). The dichotomy in the perception, conception and the response to terrorism: the case of the PKK. Counter Terrorism in Diverse Communities, 90(2011), 268.

68. Unal, M. C. (2012). The Kurdistan Workers' Party (PKK) and popular support: counterterrorism towards an insurgency nature. Small Wars \& Insurgencies, 23(3), 432-455.

69. Unal, M. C. (2012b). Counterterrorism in Turkey: Policy choices and policy effects toward the Kurdistan workers' party (PKK). Routledge.

70. Unal, M. C. (2014). Strategist or pragmatist: a challenging look at Ocalan's retrospective classification and definition of PKK's strategic periods between 1973 and 2012. Terrorism and Political Violence, 26(3), 419-448.

71. Unal, M. C. (2016a). Opening a door for return to home: impact and effectiveness of Turkish repentance laws. Studies in Conflict \& Terrorism, 39(2), 128-164.

72. Unal, M. C. (2016b). Is it ripe yet?: Resolving Turkey's 30 years of conflict with the PKK. Turkish Studies, 17(1). Available at http://www.tandfonline.com/doi/full/10.1080/14683849.2015.1124020. Accessed 03 Jan 2016. 
73. Van Bruinessen, M. (1984). The Kurds in Turkey. MERIP reports, 6-14.

74. Van Bruinessen, M. (1992). Agha, Shaikh and state: The social and political structures of Kurdistan. London: Zed books.

75. Van Bruinessen, M. (2007a). Constructions of ethnic identity in the late Ottoman Empire and Republican Turkey: the Kurds and their Others. Utrecht University. http://dspace.library.uu.nl/handle/1874/20697. Accessed 25 Jan 2015.

76. Van Bruinessen, M. (2007b). Kurds, states and tribes. Utrecht University Repository. http://dspace.library. uu.nl/handle/1874/20379. Accessed 25 Jan 2015.

77. Watts, N. F. (2006). Activists in office: pro-Kurdish contentious politics in Turkey. Ethnopolitics, 5(2), 125-144.

78. Wright, J. (1990). PIRA propaganda: The construction of legitimacy. Journal of Conflict Studies, 10(3).

79. Zartman, I. W. (2006). Negotiating internal, ethnic and identity conflicts in a globalized world. International Negotiation, 11(2), 253-272. 